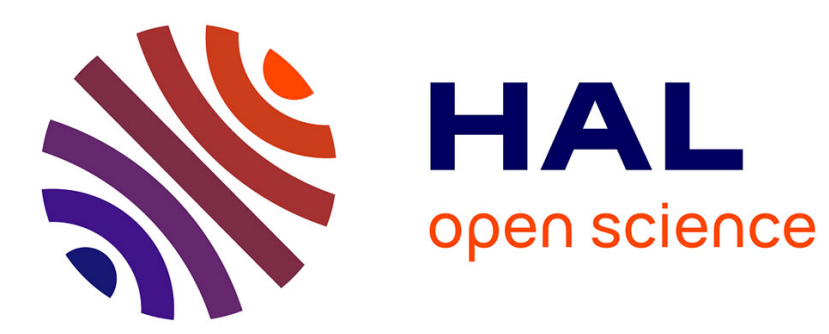

\title{
Land uplift due to subsurface fluid injection
}

Pietro Teatini, Giuseppe Gambolati, Massimiliano Ferronato, A. (tony)

Settari, Dale Walters

\section{To cite this version:}

Pietro Teatini, Giuseppe Gambolati, Massimiliano Ferronato, A. (tony) Settari, Dale Walters. Land uplift due to subsurface fluid injection. Journal of Geodynamics, 2010, 51 (1), pp.1. 10.1016/j.jog.2010.06.001 . hal-00701272

\section{HAL Id: hal-00701272 \\ https://hal.science/hal-00701272}

Submitted on 25 May 2012

HAL is a multi-disciplinary open access archive for the deposit and dissemination of scientific research documents, whether they are published or not. The documents may come from teaching and research institutions in France or abroad, or from public or private research centers.
L'archive ouverte pluridisciplinaire HAL, est destinée au dépôt et à la diffusion de documents scientifiques de niveau recherche, publiés ou non, émanant des établissements d'enseignement et de recherche français ou étrangers, des laboratoires publics ou privés. 


\section{Accepted Manuscript}

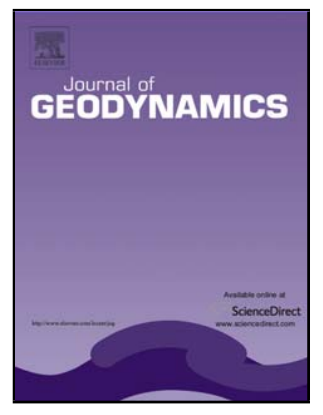

Title: Land uplift due to subsurface fluid injection

Authors: Pietro Teatini, Giuseppe Gambolati, Massimiliano

Ferronato, A. (Tony) Settari, Dale Walters

PII: $\quad$ S0264-3707(10)00093-1

DOI: $\quad$ doi:10.1016/j.jog.2010.06.001

Reference: $\quad$ GEOD 1009

To appear in: $\quad$ Journal of Geodynamics

Received date: $\quad$ 12-6-2009

Revised date: $\quad 3-6-2010$

Accepted date: $\quad$ 6-6-2010

Please cite this article as: Teatini, P., Gambolati, G., Ferronato, M., Settari, A.T., Walters, D., Land uplift due to subsurface fluid injection, Journal of Geodynamics (2008), doi:10.1016/j.jog.2010.06.001

This is a PDF file of an unedited manuscript that has been accepted for publication. As a service to our customers we are providing this early version of the manuscript. The manuscript will undergo copyediting, typesetting, and review of the resulting proof before it is published in its final form. Please note that during the production process errors may be discovered which could affect the content, and all legal disclaimers that apply to the journal pertain. 


\title{
Land uplift
}

\section{due to subsurface fluid injection}

\author{
Pietro Teatini, Giuseppe Gambolati and Massimiliano Ferronato \\ Department of Mathematical Models and Methods for Scientific Applications \\ University of Padova, ITALY
}

\author{
A. (Tony) Settari \\ Department of Chemical and Petroleum Engineering \\ University of Calgary, CANADA \\ Dale Walters \\ TAURUS Reservoir Solutions Ltd., Calgary, CANADA
}

June 2010, Revised

Submitted to: Journal of Geodynamics

Corresponding author: Pietro Teatini (teatini@dmsa.unipd.it) 


\section{Abstract}

2 The subsurface injection of fluid (water, gas, vapour) occurs worldwide for a variety of 3 purposes, e.g. to enhance oil production (EOR), store gas in depleted gas/oil fields, 4 recharge overdrafted aquifer systems (ASR), and mitigate anthropogenic land 5 subsidence. Irrespective of the injection target, some areas have experienced an 6 observed land uplift ranging from a few millimetres to tens of centimetres over a time 7 period of a few months to several years depending on the quantity and spatial 8 distribution of the fluid used, pore pressure increase, geological setting (depth, 9 thickness, and area extent), and hydro-geomechanical properties of the injected 10 formation. The present paper reviews the fundamental geomechanical processes that 11 govern land upheaval due to fluid injection in the subsurface and presents a survey of

12 some interesting examples of anthropogenic uplift measured in the past by the

13 traditional levelling technique and in recent times with the aid of satellite technology.

14 The examples addressed include Long Beach, Santa Clara Valley, and Santa Ana basin,

15 California; Las Vegas Valley, Nevada; Cold Lake and other similar sites, Canada;

16 Tokyo and Osaka, Japan; Taipei, Taiwan; Krechba, Algeria; Upper Palatinate,

17 Germany; Chioggia and Ravenna, Italy.

18 Keywords: land uplift; subsurface fluid injection; ground- and satellite-based

19 measurements; hydro-geomechanical properties; case studies 


\section{INTRODUCTION}

21 It is well known that subsurface fluid (groundwater, gas, oil, thermal water) removal

22 induces a land settlement commonly called land subsidence. Magnitude, time of 23 occurrence, and extent of the area involved depend on a large number of factors 24 including the amount of the fluid withdrawn, the pore pressure decline, the depth, volume, and permeability of the pumped formation, and the geomechanical properties of the reservoir and the overburden. For a review of some famous anthropogenically subsiding sites worldwide see Gambolati et al. (2005). The reverse, namely land uplift due to underground fluid injection, is a much less observed and recognized event although the practice of injecting fluids underground is more than a half century old.

30 Injection technology has been advancing continuously since it began to be widely used in the 1950s-1960s to re-inject formation water extracted along with the hydrocarbons, or to dispose of industrial wastes (Donaldson, 1964). The number of injection wells has grown exponentially to the point that EPA (the U.S. Environmental Protection Agency)

34 has identified about 400,000 injection boreholes in the USA alone (USEPA, 2002). The 35 injection of water-based solutions, hydrocarbons, $\mathrm{CO}_{2}$ or $\mathrm{N}_{2}$ to enhance oil production 36 (EOR) started in the $1940 \mathrm{~s}$ and soon became an accepted technique to recover 37 additional oil from reservoirs that were already depleted or waterflooded. Thermal recovery processes, used in reservoirs containing heavy (viscous) oil or bitumen, can 39 also be classified as EOR. There are also examples of water pumped into an oil field to mitigate land subsidence caused by oil production, including, for example, the case of

41 Long Beach, California, where the mitigation programme started in 1958 and was 42 carefully controlled and monitored (Rintoul, 1981).

43 Land motion related to subsurface fluid injection went unnoticed for a long time in 44 the vast majority of cases. There are a number of reasons for this. First, in most cases 
45 the disposal of fluids occurred in deserted or sparsely inhabited areas where measuring

46 surface displacements was not a priority, in part due to the large cost of levelling

47 surveys. In other instances uplift was so small that no environmental hazards were created and that no monitoring programme was really needed, or the area involved was

49 quite limited with no damages to the engineered structures and infrastructures reported

50 or even expected. Only in recent times satellite technology has offered a relatively

51 inexpensive, spatially distributed, and accurate methodology to detect ground

52 movements practically worldwide and has revealed anthropogenic uplifts of some

53 interest in terms of magnitude, size of the area involved and time of occurrence. The use

54 of Interferometric Synthetic Aperture Radar (InSAR) techniques has grown rapidly over

55 the last decade, thus facilitating immensely the detection and measurement of rising

56 areas. This is particularly true for surface movements connected with natural

57 fluctuations of the groundwater head and in areas of aquifer storage (ASR), which have

58 been systematically monitored, e.g. Galloway et al. (1998), Amelung et al. (1999),

59 Hoffmann et al. (2001), Watson et al. (2002), Hoffman and Zebker (2003), Schmidt and

60 Bürgmann (2003), Ferretti et al. (2004), Galloway and Hoffmann (2007), Bell et al.

61 (2008). Also surface and borehole tiltmeters have been widely used in recent years to

62 monitor ground heave within relatively small areas.

63 This paper provides a survey of some interesting areas in the world where

64 appreciable heave has been observed mostly as a "by-product" of fluid (water, gas,

65 vapour) injection in geological formations. The mechanics of land rebound is first

66 briefly addressed. The case studies are presented on the basis of the injection purpose,

67 i.e. EOR, ASR, gas storage, land subsidence mitigation, and geomechanical

68 characterization of the geologic formations. The focus is on the magnitude, spatial

69 distribution, and extent of the anthropogenic uplift, with some effort also devoted to

70 describing the geometry of the injected formation, fluid used, depth of disposal, 
duration of the action, and increase of the fluid pore pressure, i.e., the factors controlling the observed displacement field. Finally, two projects on land subsidence mitigation by seawater injection in the Northern Adriatic are described and discussed.

\section{MECHANICS OF LAND UPLIFT DUE TO FLUID INJECTION}

Generally speaking, uplift is caused by the migration to the ground surface of the expansion of the geological formation where the fluid is injected. The deformation of the injected porous medium is mainly driven by the in situ pore pressure $p$ and temperature $T$ variations, with the amount of the total displacement mainly controlled by the rock compressibility and thermal expansion coefficient. Based on classical thermo-poro-elastic theory (Coussy, 1995), the partial differential equations governing the rock deformation can be expressed as:

$$
G \nabla^{2} \mathbf{u}+(G+\lambda) \nabla \operatorname{divu}=\alpha \nabla p+\frac{\theta_{s}}{c_{b}} \nabla T+\mathbf{b}
$$

where $\nabla$ and $\nabla^{2}$ are the gradient and the Laplace operators, respectively, $G$ and $\lambda$ are the Lamé coefficients generally dependent on the stress path, $\mathbf{u}$ is the displacement vector, $\alpha$ is the Biot coefficient, $\theta_{s}$ is the volumetric thermal expansion coefficient for the solid phase, $c_{b}$ is the volumetric bulk compressibility, and $\mathbf{b}$ is the vector of body forces. Well-known relationships link the mechanical coefficients in equation (1) to the soil uniaxial vertical compressibility $c_{M}$. This is the fundamental geomechanical parameter which basically controls the amount of vertical soil deformation caused by $p$ change and can be acquired from in-situ measurements and lab tests.

Different types of fluids can be pumped underground, most commonly water, e.g., to recharge an aquifer system, arrest or mitigate the anthropogenic land subsidence accompanying the development and depletion of aquifers and hydrocarbon fields; but also gas, e.g., steam for $\mathrm{EOR}, \mathrm{CO}_{2}$ for long-term sequestration, or natural gas (methane) 
95 for gas storage operations. Regardless of the fluid injected, the basic mechanism

96 underlying the geomechanical response is similar with the major differences related to

97 the framework where the operation takes place, i.e. the basin geology, the magnitude of 98 the $p$ and $T$ variations, and therefore the stress path that ultimately controls the

99 deformation. For instance, recharged aquifers are typically shallow, wide, and

100 unconsolidated with the $p$ rise smaller than the previous decline, while gas/oil reservoirs

101 are deeper and more consolidated with a generally lower porosity, permeability and

102 compressibility. In this case the pressure build up can be, at least potentially, much

103 larger than the one experienced by an aquifer. The above factors can generate a very

104 different land surface response in terms of both magnitude and areal distribution 105 according to the specific case at hand.

106 The pore pressure increase in the injected formation may induce new geomechanical

107 processes which are not encountered when fluid is withdrawn. These mechanisms can

108 be more easily understood with the aid of the schematic Mohr representation of the

109 stress state shown in Figure 1 where compressive stresses are taken with the positive

110 sign. When fluid is removed $p$ decreases with respect to the original value $\left(p<p_{0}\right)$ and

111 the effective stress, according to Terzaghi's principle, increases. Hence Mohr's circle of

112 Figure 1 moves rightward, i.e. farther from the failure line bounding the envelope of the

113 allowable stress states. By contrast, when fluid is injected $p$ rises and possibly exceeds

$114 p_{0}$. In this case the effective stress decreases under the original in situ value with Mohr's

115 circle moving leftward, i.e. toward the failure line. Two failure mechanisms can be

116 experienced: (a) if Mohr's circle touches the envelope line a shear failure may occur; (b)

117 if Mohr's circle crosses the $\tau$-axis a tensile failure takes place. Moreover, a dilation (or

118 dilatancy) phenomenon, i.e. an increase of volumetric strain due to shear, could be

119 induced, thus contributing to the magnitude of the injected formation expansion. Shear

120 dilation accompanies yield and strain weakening with a permanent alteration of the 
121 fabric of the gas/oil or water bearing stratum through irreversible deformation, grain

122 rearrangement, permeability change and porosity increase, thus causing a potential

123 contribution to a measurable rebound of the land surface (Dusseault and Rothenburg,

124 1988; Settari et al., 1989, 1993). On summary, expansion of the injected formation is

125 primarily caused by a vertical effective stress release due to the pore pressure increase,

126 with the shear stress possibly contributing to deformation through dilation.

127 An additional source of deformation can be of thermal origin. If the temperature of

128 the injected fluids are lower then in-situ temperature, poroelastic and thermal effects on

129 stresses and deformations tend to counteract and may cancel each other. However, in

130 thermal EOR, where the formations involved are usually shallow, both thermal and

131 pressure effects cause expansion and are additive, resulting in appreciable surface

132 heave. According to Wang and Kry (1997) in an analysis of Cyclic Steam Stimulation

133 (CSS) operations conducted in an oil sand at Cold Lake, Alberta, Canada, the pressure

134 effects can dominate because of high injection pressures reached in the CSS process.

135 Conversely, in the Stream Assisted Gravity Drainage (SAGD) process, which uses

136 relatively lower steam injection pressure, experience in modelling (Walters, 2007)

137 shows that the thermal effects can account for $50 \%$ or more of the total heave, if the

138 nonlinearity of the geomechanical properties is taken into account.

139 It must be kept in mind that rocks typically exhibit a hysteretic mechanical behaviour

140 with stiffer properties in unloading conditions. For instance, the expansion induced by

141 pore pressure rise in the Northern Adriatic basin is only a third of that of the compaction

142 for a similar pressure decline (Baù et al., 2002; Ferronato et al., 2003).

143 In the survey of uplifted sites that follows it will be shown that anthropogenic land

144 heave can vary from a few millimetres to tens of centimetres depending on the

145 mechanism of deformation (mechanical expansion, dilatancy, thermal deformation) and

146 the several geological and geomechanical factors mentioned above. 


\section{$147 \quad 3 . \quad$ CASE STUDIES}

\section{$148 \quad 3.1 . \quad$ Injection for EOR}

\subsubsection{Cold Lake, Alberta, Canada}

150 Cold Lake is the oldest of the four developed oil sand production areas of northern

151 Alberta, Canada. It is producing from the $15-30 \mathrm{~m}$ thick Clearwater sand lying at a 152 depth of about $450 \mathrm{~m}$. The sand is primarily quartz and in the best quality area is quite 153 homogeneous and densely packed; it exhibits dilation when sheared. Above the

154 Clearwater is the Grand Rapids formation consisting of interbedded shale/sand 155 sequences (often containing small gas reservoirs), and the Colorado shale group. A 156 fresh water sandy aquifer at a depth of 100-150 m overlies the Colorado shale. The

157 bitumen viscosity in the Clearwater varies between 50,000 and 100,000 cp at an in-situ 158 temperature close to $13{ }^{\circ} \mathrm{C}$. The area was developed initially by Imperial Oil Ltd. using

159 CSS consisting of cycles of steam injection (30-40 days) at fracturing pressure followed 160 by a production period of several months. Currently, the SAGD process is favoured for 161 new projects.

162 In CSS, the deformations from the pressure cycles (typically between $10 \mathrm{MPa}$ to 2

$163 \mathrm{MPa}$ or less) and thermal expansion combine to produce an overall heave of $10-35 \mathrm{~cm}$.

164 Wang and Kry (1997) show the data and simulation results for an area of 3 well "pads" 165 (each consisting of 4 rows of 5 wells) for the period between January 6 and February 16624,1989 . At the beginning of this period, injection and production was balanced, but

167 due to previous injections, the maximum heave was already about $20 \mathrm{~cm}$, as shown by 168 the baseline on Figure 2a. During the period studied, most of the wells were injecting 169 and this resulted in an additional $5-7 \mathrm{~cm}$ of uplift. This magnitude is typical and the 170 heave generally increases with time as the area heats up and accumulates dilation strain. 171 Wong and Lau (2008) confirmed this magnitude by semi-analytical calculations using 
172 the nucleus of strain concept. Satellite measurements of the Cold Lake project have

173 been described by Stancliffe and van der Kooij (2001). As shown in Figure 2b, large

174 deformation changes can occur over small periods of time (2-3 months). They stated

175 that their best data show that the total deformation can reach $36 \mathrm{~cm}$ during a single 176 month.

177

178

180

181

184

\subsubsection{Shell Peace River, Canada}

The Peace River oil sands deposits cover an area of about $47 \times 10^{7} \mathrm{~m}^{2}$ west of the Cold Lake and Athabasca areas. The resource, containing bitumen of viscosity of 10,000 to $200,000 \mathrm{cp}$ in a formation $30 \mathrm{~m}$ thick buried at a depth of $600 \mathrm{~m}$, has been developed by Shell Canada, using modifications of the CSS technology. Injection takes place at pressures of above $13 \mathrm{MPa}$ (the in-situ vertical stress), thereby producing formation fracturing. An extensive monitoring program, consisting of microseismic, surface time-lapse seismic, time-lapse 3D vertical seismic profiles, surface tiltmeters and InSAR, was implemented to better understand the production mechanisms, and determine the reservoir volume change. In particular, tiltmeter data were used extensively. The data interpretation indicated a similar magnitude of heave as that as Cold Lake, as shown in Figure 3 (Du et al., 2005). McGillivray et al. (2006) reported that during the first year (Oct. 2002-Oct. 2003), the reservoir volume increased by $400,000 \mathrm{~m}^{3}$

\subsubsection{Athabasca oil sands, Canada}

The Underground Test Facility (UTF), located in the Athabasca area, was the first field scale project designed to test the SAGD recovery method for oil sands. UTF operates at a depth of about $140 \mathrm{~m}$. During the first phase, started in 1984, 3 pairs of short horizontal wells were drilled from an underground tunnel accessed by a vertical shaft. The second phase followed with 3 pairs of long $(500 \mathrm{~m})$ horizontal wells from 
197 which commercial quantities of bitumen were produced (see O'Rourke et al., 1999, for

198 review). Flue gas was also injected at a later stage (Yee and Stroich, 2004) and the 199 project is now in a commercial stage. Separate vertical wells were drilled to monitor 200 temperature and deformations. About $5 \mathrm{~cm}$ of heave was recorded in the centre of the 201 deforming area from September 1993 to in April 1994, as shown in Figure 4. As the 202 project matured, the heave increased up to $30 \mathrm{~cm}$ in 2001.

203 Following the success of the UTF project, several commercial projects using SAGD 204 technology started, and are now producing in the Athabasca area. A complete set of 205 heave surveys is available for the MacKay River project of PetroCanada (Petro-Canada, 206 2008) and the Firebag project of Suncor (Suncor, 2008).

207 The MacKay River SAGD produces from the McMurry sand at a depth of about 100 $208 \mathrm{~m}$, at an operating pressure of $1.7 \mathrm{MPa}$ and steam temperature of $205^{\circ} \mathrm{C}$. Deformations 209 were measured by repeated monitoring of 97 monuments (leveling) and supplemented 210 by an array of tiltmeters and microseismic monitoring. In December 2007, an additional

21167 monuments were installed. The heave contours between the baseline surveys of

212 December 2002 and December 2007 are shown in Figure 5a. The overall heave pattern 213 follows the orientation of the injection/production well pairs running NE to SW. The 214 heave exceeds $30 \mathrm{~cm}$ in several areas and reaches a maximum of $37 \mathrm{~cm}$ over the field. 215 Heave along a profile oriented perpendicular to the well pairs is shown for three 216 different times in Figure $5 b$.

217 The Firebag project of Suncor also produces from the McMurry formation but it is in 218 an earlier stage of development. Heave surveys have been conducted yearly from 2004 219 to 2008 and the cumulative heave during this period has reached $15.3 \mathrm{~cm}$, with the 220 incremental heave over the last year having a maximum of $4.9 \mathrm{~cm}$. Coupled 221 geomechanical and thermal flow studies carried out by the authors on various Athabasca 222 sites confirm the range of uplift observed at the sites discussed above (i.e., 20-35 cm). 
223 The main mechanisms contributing to heave include thermal expansion, decrease of the

224 effective stress, nonlinear decrease of stiffness associated with decrease of effective

225 stress and change in Poisson's ratio.

\section{3.2. Injection for ASR}

227

228

229

230

231

232

233

234

235

236

237

238

239

240

241

242

243

244

245

246

\subsubsection{Santa Clara Valley and Santa Ana Basin, California}

The Santa Clara Valley is a structural trough running $110 \mathrm{~km}$ southeast of San Francisco. The valley is bounded on the southwest by the Santa Cruz Mountains and the San Andreas fault, and on the northeast by the Diablo Range and the Hayward fault. The fresh-water-bearing sediments forming the groundwater reservoir within the valley were mainly deposited during the Quaternary. They include semi-consolidated deposits of the Pliocene and Pleistocene epochs, and unconsolidated alluvial and bay deposits of the Pleistocene and Holocene epochs consisting of poorly sorted conglomerate, sandstone, siltstone, and clay as much as $600 \mathrm{~m}$ thick. Coarse-grained deposits predominate in the alluvial fans near the valley margins where the stream gradients are steeper. The proportion of clay and silt layers increases toward the San Francisco Bay (Poland, 1984).

From the early 1900 s agriculture depended heavily on groundwater for irrigation. As farming was progressively replaced by urban and industrial development in the 1940s, the withdrawal continued to increase as the population grew. A decrease in rainfall during the first half of the twentieth century along with an increase in the pumping rate resulted in a significant drop of the artesian head, by as much as $80 \mathrm{~m}$ between 1912 and 1966. The well depth ranges from 90 to $360 \mathrm{~m}$. Total annual groundwater withdrawal approached $250 \mathrm{Mm}^{3}$ by 1960 (Ingebritsen and Jones, 1999). The piezometric head decline caused as much as $4 \mathrm{~m}$ of land subsidence (Poland, 1984). 
The Santa Clara Valley was the first area in the United States where organized

248 remedial actions were undertaken against groundwater overdraft with land subsidence substantially halted by about 1969. Importation of surface water reduced the subsurface pumping and allowed for an effective program of aquifer recharge leading to a recovery

251 of groundwater levels. Such a program began in the 1960s and continues presently.

252 Using InSAR Schmidt and Bürgmann (2003) showed the regional uplift of the ground 253 surface in the Santa Clara Valley occurred from 1992 to 1999 (Figure 6a). A maximum 254 upheaval of about $4 \mathrm{~cm}$, reflecting the poroelastic response of the confined aquifer system, has been measured northward. In the south-eastern part of the valley a seasonal uplift signal is superimposed onto the long-term trend (Figure 6b). The long-term and seasonal displacements result from head changes in the aquifer system in the elastic range of stress. Observed water level fluctuations and borehole extensometer records provide evidence that the vertical compressibility of the confined aquifer system in the

260 virgin stress range is from 20 to 100 larger than the average $c_{M}$ in the elastic range 261 (Poland and Ireland, 1988).

262 InSAR investigations (Bawden et al., 2001) show that the $20 \times 40 \mathrm{~km}$ Santa Ana

263 Basin in the metropolitan area of Los Angeles displays a seasonal fluctuation with a 5 $264 \mathrm{~cm}$ uplift during the late fall through mid-spring (Figure 7) and $6 \mathrm{~cm}$ subsidence during 265 the late spring through mid-fall. Seasonal water table changes of the order of $30 \mathrm{~m}$ 266 indicate a close relationship between aquifer management and land deformation as 267 measured by InSAR. The aquifer is recharged all year round and is pumped during May 268 - September to meet the summer water demand. Approximately $78 \%$ of the water 269 pumped from the basin in 1996-1997 came from artificial recharge through surface 270 spreading basins located in the proximity of the Santa Ana River and Santiago Creek.

271 The produced water-bearing units span the depth interval between 50 and $600 \mathrm{~m}$ below 272 the ground surface (MWDSC, 2007). 


\subsubsection{Las Vegas Valley, Nevada}

The Las Vegas Valley is located in a structurally controlled alluvial basin containing up to $1500 \mathrm{~m}$ of unconsolidated sediments during the Pliocene through Holocene age. Coarse-grained (sand and gravel) alluvial-fan deposits derived from the surrounding mountain ranges form broad piedmonts around the periphery of the valley, while predominantly fine-grained (silt and clay) compressible materials underlie the central part of the valley. Intervening sequences of both coarse- and fine-textured sediments give rise to a well-developed multi-aquifer system cut by several Quaternary faults extending from the underlying bedrock to the ground surface. Most of the groundwater in the aquifer system originates from the precipitation in the Spring Mountains to the west.

Groundwater has greatly promoted the development of Las Vegas since the early 1900s when the first wells were drilled in the area. The Las Vegas metropolitan area increased in population from 0.8 million in 1990 to more than 1.5 million in 2000 . Although natural springs historically provided water to this arid valley (the average precipitation in a year is about $12-20 \mathrm{~cm}$ ), groundwater pumping was drastically increased to help meet the rising demand. Total pumpage reached a peak of more than $100 \mathrm{Mm}^{3} /$ year in the late $1960 \mathrm{~s}$, remaining steadily above $70 \mathrm{Mm}^{3} /$ year until the $1990 \mathrm{~s}$. Groundwater is mainly pumped from the upper $600 \mathrm{~m}$ of unconsolidated sediments. The long-term effects of pumping produced a regional decline of water levels of as much as 90 m by 1990 with more than $1.7 \mathrm{~m}$ of land subsidence measured by levelling surveys through 2000 (Bell et al., 2002).

Since 1988 the Las Vegas Valley Water District (LVVWD) has maintained a groundwater recharge program in to augment the local water supply during periods of high demand. Water is recharged primarily in the coolest months using treated surface water imported from the nearby Lake Mead on the Colorado River. Since the beginning 
299 of the artificial recharge program, water levels have stabilized and recovered by as

300 much $30 \mathrm{~m}$ from 1990 to 2005 (LVVWD, 2005). Persistent Scatterer InSAR for the

301 periods $1995-2000$ and 2003-2005 show a general reduction of the subsidence rate and a

302 broad area of uplift with velocities as much as $1 \mathrm{~cm} /$ year adjacent to the easternmost

303 margin of the main artificial recharge zone (Figure 8). Seasonal displacements of the

304 order of $1 \mathrm{~cm}$ are superimposed on the larger uplift trend, indicating that there are both

305 short- and long-term components in the elastic response of the system. The maximum

306 seasonal uplift occurs during January through March each year during the peak period

307 of artificial recharge (Amelung et al., 1999; Bell et al., 2008).

308 Based on the available subsidence/uplift measurements, the records of water level 309 changes, and the thickness of the compacting/expanding geologic units, the ratio $r$

310 between the inelastic (virgin loading) and elastic (unloading/reloading) compressibility

311 of the aquifer system has been estimated to be in the interval of 3 to 20 (Hoffmann et

312 al., 2001; Bell et al., 2008).

\section{$313 \quad$ 3.3. Injection for gas storage}

\section{3.3.1. Krechba field, Algeria}

315 The Krechba field is a gas reservoir located in the Algerian Sahara desert at a burial

316 depth of about $2000 \mathrm{~m}$. The 20 -m thick producing layer lies on a north-northwest

317 trending anticline and mainly consists of quartzose fine-grained sandstone of Early

318 Carboniferous period. The overburden comprises of a sequence of alternating

319 mudstones and sandstones. The horizontal stress field in the basin is highly anisotropic

320 with faults on the flanks of the anticline trending north-northwest. The gas produced

321 from the Krechba field contains a high mole fraction of $\mathrm{CO}_{2}$ which must be separated

322 and disposed of for both economic and environmental reasons. The $\mathrm{CO}_{2}$ is re-injected

323 into the reservoir through three nearby wells located at about $8 \mathrm{~km}$ northeast of the 
324 cluster of the production wells. At the reservoir pressure the $\mathrm{CO}_{2}$ behaves as a

325 supercritical fluid with a density of about $0.85 \mathrm{~kg} / \mathrm{dm}^{3}$. The well-head injection pressure

326 varies during the operations with an average value of $15 \mathrm{MPa}$ and peak values achieving $32718 \mathrm{MPa}$.

328 As part of a $\mathrm{CO}_{2}$ sequestration research project, the PSInSAR technique (Ferretti et 329 al., 2001; Colesanti et al., 2003) has been used to monitor the injection effects on the 330 ground surface (Vasco et al., 2010). The study is based on satellite radar images 331 obtained from July 12, 2003 to March 19, 2007. With this approach, stable scatterers are 332 identified using a statistically based analysis of the phase and amplitude characteristics 333 of the energy reflected by the earth surface. A subset of such scatterers is denoted as 334 permanent and used to estimate the atmospheric and orbital errors. In the Krechba field 335 case the quality of the data is particularly good because the rock outcrops in the desert 336 area are stable reflectors. The mean vertical ground velocity for the investigated 20033372007 time interval as provided by the PSInSAR data analysis is shown in Figure 9. The 338 areas shown in blue are increasing in elevation by more than $5 \mathrm{~mm} /$ year and are clearly 339 correlated with the location of the three injection wells. The cumulative upheaval 340 measured above the Krechba field amounts to about $2 \mathrm{~cm}$ with a rather uniform areal 341 distribution.

\subsubsection{Lombardia field, Italy}

343 To cope with the energy demand in the cold season, gas and oil companies dispose of

344 methane in exhausted reservoirs during summer and extract it during winter. In Italy 345 Stogit S.p.A. manages a number of depleted gas fields for storage purposes. The 346 Lombardia field, located in the Po river plain, Northern Italy, is one such reservoir, 347 consisting of three mineralized layers (named A, B and C) made of turbiditic sediments 348 deposited during the late Pliocene epoch with about 30-m thick shale caprocks. Layer C, 
349 about $100-\mathrm{m}$ thick and $1200-\mathrm{m}$ deep, is the main pool containing about $93 \%$ of the

350 overall gas originally in place. About $2,700 \mathrm{MSm}^{3}$ were produced from pool $\mathrm{C}$ between

3511981 and 1986, and since 1986 pool C has been used for storage purposes. The largest

352 pore pressure drawdown achieved in 1986 was about $3 \mathrm{MPa}$. In the following years

353 water ingression from the surrounding aquifer led to a partial recovery of about $2 \mathrm{MPa}$.

354 Currently, the average operative pore pressure is about $1 \mathrm{MPa}$ below the original value,

355 with a difference of $2.5 \mathrm{MPa}$ between the maximum at the end of the storage phase and

356 the minimum at the end of withdrawal. The maximum pore pressure in the reservoir

357 exceeds the original in situ value by about 3\% (IGU, 2003).

358 An integrated monitoring system has been implemented above the Lombardia field to

359 monitor the land movements induced by the cyclic injection-extraction activity operated

360 in the reservoir. From 2003 to 2007 traditional high-precision levelling surveys were

361 carried out yearly along with a much more frequent PSInSAR analysis. The levelling

362 surveys reveal that the region above the field exhibits a slight upheaval trend with a

363 positive vertical ground velocity of about $1 \mathrm{~mm} /$ year. The PSInSAR data do show

364 cyclic ups and downs phased with the pressure variation within the reservoir. An

365 example of the vertical displacements vs. time for a few pixels from the PSInSAR

366 analysis located above the field is given in Figure 10, with the magnitude of the

367 occurrence gradually dissipating on the observation points farther from the reservoir.

368 Apart from the general upheaval trend, that is most likely of tectonic origin, land motion

369 appears to be elastic with an average difference between the peak values of about $1 \mathrm{~cm}$.

370 A spatial kriging interpolation of the satellite images was used to map the areal

371 distribution of the vertical displacements above the reservoir. As an example, Figure 11

372 shows maps over the periods November 2005 - April 2006 (a) and April 2006 -

373 November 2006 (b). In the former time interval gas is withdrawn and land subsides, and

374 in the latter gas is injected and the land rises by about the same magnitude. Moving 
375 farther from the reservoir boundary the vertical displacements quickly vanish and

376 appear to be un-influenced by gas storage.

377 A modeling study by Castelletto et al. (2010) and Teatini et al. (2010) shows that the

378 PS records are successfully matched with a finite element model using a loading

379 unloading-reloading compressibility ratio of 4.

\section{$380 \quad 3.4$ Injection for land subsidence mitigation}

\section{3.4.1. Wilmington, Long Beach, California}

382 The Wilmington oil field is a broad asymmetrical anticline extending lengthwise 383 approximately $18 \mathrm{~km}$ in a SE-NW direction and about $5 \mathrm{~km}$ in the SW-NE direction

384 below Long Beach, in the southwestern part of the Los Angeles basin, California. The

385 reservoir is made of seven overlying oil-bearing formations of the Pliocene and

386 Miocene epoch spanning the depth range $600-2000 \mathrm{~m}$ below $\mathrm{m} . s .1$. The pools are

387 divided into six structural blocks by five major faults that restrict the fluid flow between

388 the blocks. The sediments predominantly comprise rather loose and unconsolidated

389 sands and siltstones, with intervening shale layers (Mayuga and Allen, 1970).

390 Because of limited waterdrive activity, the pressure decline in the oil reservoir was

391 relatively fast. By the mid-1960s about $9 \mathrm{MPa}$. of drawdown at $900 \mathrm{~m}$ depth, and nearly

$3929 \mathrm{~m}$ of land subsidence had occurred since the onset of production (Allen and Mayuga,

393 1970). The subsidence above the field was clearly recognized in 1941 when the U.S.

394 Coast and Geodetic Survey surveyed the levelling lines between San Pedro and Long

395 Beach, which had been previously monitored in 1933-1934. Subsequent measurements

396 showed increasing subsidence up to the maximum $9 \mathrm{~m}$ value experienced in 1965

397 (Colazas and Olson, 1983). Results from precision casing collar surveys, i.e. the

398 periodic monitoring of the shortening (or lengthening) of well casing joints due to the 
compaction (or expansion) of the oil-bearing formations (Law, 1950), provided

400 evidence that compaction occurred over the 650-1100 m depth interval.

401 In order to mitigate land settlement a massive water injection program was 402 implemented in the late 1950 s. Approximately $175,000 \mathrm{~m}^{3} /$ day of water were injected 403 into the field during the 1960s (Mayuga and Allen, 1970), declining to $90,000 \mathrm{~m}^{3} /$ day 404 by the mid-1990s (Otott Jr and Clark, 1996). Both seawater withdrawn from shallow 405 beds directly connected with the ocean and formation water produced along with the oil 406 were used for injection. Subsidence stopped over a large portion of the field with the 407 subsiding area reduced from $50 \mathrm{~km}^{2}$ to $8 \mathrm{~km}^{2}$. The settlement rate at the historical centre 408 of the subsidence bowl was reduced from a maximum of $71 \mathrm{~cm} /$ year in 1951 to zero in 4091968 , and in certain areas a surface rebound up to $33 \mathrm{~cm}$ was observed (Figure 12a). In 410 the newest portions of the Wilmington field waterflooding and oil production began 411 almost simultaneously. No significant subsidence occurred in those areas with over412 injection generating a $20 \mathrm{~cm}$ increase of the original ground elevation (Figure 12b) 413 (Colazas and Olson, 1983).

414 In-situ measurements by casing joints (Allen and Mayuga, 1970), lab tests at high 415 confining pressures (Vesiĉ and Clough, 1968) and numerical modelling (Kosloff et al., 416 1980a, 1980b) suggest that the Wilmington sandy formations under unloading/reloading 417 are from 2 to 8 times stiffer than for virgin loading conditions.

\subsubsection{Tokyo and Osaka, Japan}

419 Over the 1950s-1960s a significant lowering of the groundwater level occurred in all 420 the major cities of Japan because of an uncontrolled overdraft of the shallow multi421 aquifer systems. For example, the resulting land settlement in Tokyo was reported to be 422 about $4.5 \mathrm{~m}$ relative to the ground elevation at the early 1920s (Yamamoto, 1995) with a 423 number of serious related social problems. Full scale development of the aquifer system 
424 in Tokyo started in 1914. After that time, the number of deep wells increased very

425 quickly. The hydraulic head kept on falling year after year due to pumping from the 426 upper $300 \mathrm{~m}$ thick multi-aquifer, and after a temporary recovery during World War II, it 427 achieved its lowest value of about $-70 \mathrm{~m}$ below the mean sea level of the Tokyo Bay 428 (Yamamoto, 1984).

429 To mitigate the anthropogenic settlement new regulations were established from the 430 early 1970s throughout Japan to control of the groundwater use. As a major 431 consequence groundwater level has increased over the last decades in all the major 432 Japanese cities, including Tokyo and Osaka, and this has been accompanied by a 433 general ground upheaval. This has been carefully monitored by local administrations in 434 order to prevent possible deformations of the underground structures. As an example, 435 Figure 13 shows the piezometric increase and the associated vertical uplift for the city 436 of Tokyo. Inspection of Figure 13a reveals the close relationship between aquifer

437 recovery occurring after the implementation of the 1970 regulations and land upheaval, 438 which amounts to about $20 \mathrm{~cm}$. The areal distribution of the Tokyo uplift from 1991 to 4392005 is shown in Figure 13b, with several zones experiencing an uplift of more than 5 $440 \mathrm{~cm}$ and a slightly irregular pattern. Similar results are found for the city of Osaka where 441 several urban areas experienced uplift of about $3 \mathrm{~cm}$ in 5 years (Sreng et al., 2009).

\subsubsection{Taipei, Northern Taiwan}

443 Taipei City is the political and economical centre of Taiwan with a dense population 444 of about 3 million inhabitants plus several million people in the surrounding suburban 445 areas. Like many other big cities in the world, early development of the city was 446 enhanced by the development of the groundwater resources. The city centre lies on 300$447 \mathrm{~m}$ thick late-Quaternary fluvial deposits laid down over deformed Miocene bedrock 448 starting from about 400,000 years ago. 
Groundwater pumping mainly occurred from 1955 to 1970 from a confined aquifer

450 lying between 50 and $140 \mathrm{~m}$ depth below the ground surface. Piezometric head has

451 decreased by more than $40 \mathrm{~m}$ with the lowest value reached in 1975 . The massive 452 pumping was accompanied by large land settlements amounting to as much as $2.2 \mathrm{~m}$ in 453 the city centre (Wu, 1977). In order to mitigate the subsidence and prevent any possible 454 associated damages, the government stopped the use of groundwater in the Taipei Basin 455 during the early 1970s. The settlement rate has significantly decreased as the hydraulic 456 head gradually recovered and stabilized after approximately the late 1990s. The 457 establishment of a fine network of levelling benchmarks has allowed for accurate 458 monitoring and control of the ground movements during the recovery. The behaviour of 459 the post-pumping ground elevation is characterized by a relatively long period of 460 declining subsidence followed by a period of uplift from 1989 to 2003. Most surface

461 rebound was observed in the central to eastern portion of the basin, roughly 462 corresponding to the area of maximum subsidence. From 1989 to 2003 most of the 463 Taipei Basin, except for its westernmost margin, experienced a rather homogeneous 464 uplift of 7 to $10 \mathrm{~cm}$ with a maximum of $17 \mathrm{~cm}$ (Figure 14a). The largest rate, more than $4651 \mathrm{~cm} /$ year, was measured between 1989 and 1994 (Figure 14b). The observed elastic 466 rebound was used to quantify a ratio of about 10 between the aquifer-system 467 compressibility under virgin loading and unloading/reloading conditions (Chen et al., 468 2007).

\subsubsection{Chioggia Mare, Northern Adriatic, Italy}

470 ENI-E\&P, the Italian national oil company, has recently advanced a plan for the 471 development of a number of gas fields (about 15) located in the Northern Adriatic. The 472 largest field, named Chioggia Mare, is the closest to the coastline (the westernmost 473 margin of the field is $12 \mathrm{~km}$ from the city of Chioggia, south of Venice). Gas production 
474 from Chioggia Mare raises some concerns about the risk of contributing to

475 anthropogenic settlement of Chioggia and the surrounding lagoon, including Venice. To

476 offset this environmental hazard ENI-E\&P designed a project of land subsidence

477 mitigation using two deep seawater injection wells located halfway between the field

478 and the coastline. The Italian Ministry of Environment gave the University of Padova,

479 Department of Mathematical Models and Methods for the Scientific Applications

480 (DMMMSA), the task of checking the environmental sustainability of the ENI-E\&P

481 mitigation programme, with the aid of ad hoc numerical models able to reliably predict

482 the expected land subsidence in the presence of the injection wells. The Chioggia Mare

483 gas field is seated at a 1100-1400 m depth and consists of four pools. The upper pools

484 ( $\mathrm{C}$ and $\mathrm{C} 2$ ) are formed by a structural trap and the lower ones (E and $\mathrm{Ea})$ pinch out

485 against a thick clayey formation (called Santerno), which represents a natural hydraulic

486 barrier. The estimated total gas withdrawn from Chioggia Mare over its 12-year

487 production life will be about $5,000 \mathrm{MSm}^{3}$. Pools $\mathrm{C}$ and $\mathrm{C} 2$ are surrounded by a strong

488 lateral and bottom waterdrive. The lateral aquifer partially encompassing pools $\mathrm{E}$ and

489 Ea is much weaker. More detailed information about the geology and the properties of

490 Chioggia Mare are provided in Teatini et al. (2000).

491 Injection of seawater is planned to take place in pool C lateral aquifer at a rate of $4925,000 \mathrm{~m}^{3} /$ day for 25 years after the inception of gas production. The injected water will 493 be properly filtered to remove particles larger than 5-10 $\mu \mathrm{m}$ that could cause a reduction 494 of the aquifer permeability. It will be also chemically treated for compatibility with the 495 in situ water to avoid the activation of corrosion of the well intakes. Figures 15a and $49615 \mathrm{~b}$ show the simulated fluid pore pressure variation in pool $\mathrm{C}$ and the associated 497 waterdrive predicted at the end of the field production life without and with the injection 498 of water. It can be noted that the depressurization caused by gas pumping does not 499 propagate coastward because of the barrier effect exerted by the injection wells. Note 
500 also the overpressure experienced by the waterdrive in the vicinity of the injection

501 boreholes. The simulated influence of injection on vertical ground displacement is

502 shown in Figures $15 \mathrm{c}$ and $15 \mathrm{~d}$. In the present case, water injection helps mitigate the 503 expected land subsidence and does not necessarily induce an appreciable anthropogenic

504 heave. Figure 16 shows the simulated vertical ground displacement in Chioggia without 505 and with the injection wells for the various plausible combinations of hydro-geo-

506 mechanical parameters investigated by Gambolati et al. (1998) in their report to the

507 Ministry. As an example, in the most favourable scenario using geomechanical

508 properties derived from lab tests, the predicted land uplift occurs 13 years after the 509 cessation of gas withdrawal and is on the order of $6 \mathrm{~mm}$.

510 3.4.5. Ravenna, Adriatic coastline, Italy

511 The Ravenna Adriatic coastline is underlain by a major gas field, named Angela-

512 Angelina (Figure 17a), that extends down to 2900-4000 m depth and consists of a very

513 large number of gas pools (about 300) separated by intervening clayey layers and

514 crossed by a number of geological faults. Initially, the gas reserve was estimated to be

$51522,000 \mathrm{MSm}^{3}$ of which about 12,000 were produced as of January 2002 and 10,000

516 more are planned to be pumped out over the following 25-30 years. In a few depleted

517 pools the maximum fluid pore pressure drawdown has amounted to as much as $35 \mathrm{MPa}$.

518 The land subsidence caused by gas production in the vicinity of Angela-Angelina has

519 received the attention of a number of studies (Teatini et al., 1998; Gambolati et al.,

520 1999; Schroot et al., 2005) and is a matter of concern regarding the stability of the

521 Ravenna coastland. To mitigate it, ENI-E\&P has implemented an experimental project

522 called "Angela Pressure Maintenance" with the final objective to oppose the anticipated

523 coastland settlement through the injection of water in the aquifer connected to the 
524 reservoir over the depth interval $3100-3700 \mathrm{~m}$. The ENI-E\&P injection project was 525 designed in 2001 and consists of three phases (Figure 17b):

526 1- re-injection of the formation water, i.e. the water extracted along with the gas from Angela-Angelina and the nearby offshore fields Amelia, Antares and Porto Corsini Mare. At the beginning of the operation in 2003, the injection rate was $150 \mathrm{~m}^{3} /$ day and soon increased to $300 \mathrm{~m}^{3} /$ day with the addition of the seawater obtained with the aid of the Beach Management System (BMS) (Ciavola, 2005; Piccini et al., 2006) and chemically treated for compatibility with the situ water;

2- increase of the injection rate using additional wells from the cluster Angela;

benefits in terms of a delayed propagation of the depressurization below the coastline

538 have been observed. No evidence is so far available of any significant mitigation of land

539 subsidence. However, the ENI-E\&P pressure maintenance experiment is of great 540 practical interest, and especially so in view of the planned progressively increased rate

541 of injection. Future modelling predictions and field measurements will help reveal the 542 hopefully effective impact of the above programme.

543 By the use of recent geophysical logs and marker measurements from deep offshore

544 boreholes drilled in the vicinity of Angela-Angelina, Baù et al. (2002) estimate a ratio $\mathrm{r}$

545 between loading and unloading-reloading $c_{M}$ ranging from 3 to 2 over the depth interval 546 3000-4000 m. However, because of the large injection depth, the medium 547 compressibility in expansion is expected to be about one order of magnitude smaller 548 than that of the shallower Chioggia Mare field. 


\subsection{Injection for geomechanical characterization. Upper Palatinate, Bavaria,}

\section{Germany}

551

552 improve knowledge of coupled hydro-geomechanical processes and characterize the affected subsurface porous medium was performed from June 2004 to April 2005 in the Upper Palatinate, Eastern Bavaria, Germany (Kumpel et al., 2006). Water was injected at a rate of about $290 \mathrm{~m}^{3} /$ day to a total of $84,000 \mathrm{~m}^{3}$ through an open hole that was 3850-4000 m deep. Land deformation was monitored by high-resolution borehole tiltmeters installed at 5 locations (Berg, Eiglasdrof, Stockau, Mittelberg and Pullersreuth) at a variable $1.5-3.3 \mathrm{~km}$ distance from the injection well denoted as

Kontinentale Tiefbohrung der Bundesrepublik Deutschland (KTB) (Jahr et al., 2005, 2006). The pore pressure increase exceeded $10 \mathrm{MPa}$ at KTB over the injection time and induced a land deformation that was detected by the tiltmeter array. The measured tilts

562 were reproduced with the aid of a finite element model. The results (Jahr et al., 2008)

563 reveal a maximum anthropogenic uplift of approximately $3 \mathrm{~mm}$ above the injection 564 point which dissipates quickly as one moves far from it (Figure 18a). Figure 18b shows the modelling reconstruction of the tiltmeter measurements around KTB.

\section{DISCUSSION AND CONCLUSIONS}

567 A survey of sites worldwide where underground fluid (water, gas, steam) injection 568 has caused a measurable land uplift (or heave) has been performed. Fluid is injected for

569 a variety of purposes, from enhancing oil production to storing gas in depleted gas/oil

570 fields, recharging pumped aquifers, disposing of industrial liquid wastes and mitigating

571 anthropogenic land subsidence. Vertical land displacement is measured using traditional

572 levelling, tiltmeters, or, most recently and relatively inexpensively, with the aid of the 573 satellite interferometry. Land may rise as a consequence of the migration to ground 
574 surface of the injected formation expansion. This is due primarily to the release of the

575 effective intergranular stress and secondarily to the shear dilation (or dilatancy) on 576 condition that the induced fluid pore overpressure is large enough so as the yield surface 577 (or friction line) is intersected by the Mohr-Coulomb circles. Thermal expansion may 578 also contribute significantly to the observed heave. Careful inspection of each single 579 occurrence reveals that:

$580 \quad 1-$ the observed land uplift may vary from a few millimetres to tens of centimetres an innovative defence from periodical flooding that affect high-value coastal areas that are experiencing land settlement and/or seal level rise due to climate changes. Recent 
600 600- to 800-meter-deep brackish aquifer underlying Venice, Italy, might induce an

601 upheaval of this much loved city by $25-30 \mathrm{~cm}$ over 10 years. Such an uplift would be

602 enough to offset the most likely scenario of relative sea level rise expected in 2100

603 (Carbognin et al., 2009).

604 A second point enlightened by the present survey regards the ratio $r$ of virgin to second

605 cycle elastic compressibility $c_{M}$. The available data are summarized in Figure 19 and

606 show that, almost irrespectively of the site, $r$ tends to increase for shallower depth. If at

607 very large depths the virgin $c_{M}$ is only from two to three times the elastic $c_{M}$, in shallow

608 aquifer systems $(\sim 50-300 \mathrm{~m})$ the former can be one order of magnitude larger than the

609 latter. The actual prediction of the expected medium expansion due to fluid injection,

610 and thus the related ground uplift, requires the knowledge of $c_{M}$ in the unloading-

611 reloading cycle. On first approximation, it might be obtained from the more frequently

612 and easily known $c_{M}$ in virgin loading and a $r$ estimate based on the depth of the

613 injected formation. For sure, a more accurate evaluation requires a site-specific

614 investigation. This is why, concerning the project mentioned above of anthropogenic

615 Venice raising, a pilot ad hoc injection experiment has been recently advanced

616 (Castelletto et al., 2008).

617 Acknowledgments. The work has been partially developed within the Research

618 Programme "The Venice Lagoon in the framework of climate changes, mitigation

619 strategies, adaptation and evolution of land uses" funded by Magistrato alle Acque di

620 Venezia (Venice Water Authority) and CORILA

621 


\section{REFERENCES}

622 Allen, D.R., Mayuga, M.N., 1970. The mechanics of compaction and rebound, 623 Wilmington oil field, Long Beach, California, USA. In Tjson, L.J., (Ed.), Land 624 Subsidence, Proceedings of the Tokyo Symposium 1969. IAHS Publication no. 89, 625 pp. $410-422$.

626 Amelung, F., Galloway, D.L., Bell, J.W., Zebker, H.A., Laczniak, R.J., 1999. Sensing 627 the ups and downs of Las Vegas: InSAR reveals structural control of land subsidence 628 and aquifer-system deformation. Geology 27, 483-486.

629 Baù, D., Ferronato, M., Gambolati, G., Teatini, P., 2002. Basin-scale compressibility of 630 the Northern Adriatic by the radioactive marker technique. Geotéchnique 52, 605$631 \quad 616$.

632 Bawden, G.W., Thatcher, W., Stein, R.S., Hudnut, K.W., Peltzer, G., 2001. Tectonic 633 contraction across Los Angeles after removal of groundwater pumping effects. $634 \quad$ Nature 412, 812-815.

635 Bell, J.W., Amelung, F., Ramelli, A., Blewitt, G., 2002. Land subsidence in Las Vegas, 636 Nevada, 1935-2000: New geodetic data show evolution, revised spatial patterns, and 637 reduced rates. Environmental and Engineering Geoscience 8, 155-174.

638 Bell, J.W., Amelung, F., Ferretti, A., Bianchi, M., Novali, F., 2008. Permanent scatterer 639 InSAR reveals seasonal and long-term aquifer system response to groundwater 640 pumping and artificial recharge. Water Resources Research 44, doi: $641 \quad 10.1029 / 2007$ WR006152.

642 Carbognin, L., Teatini, P., Tomasin A., Tosi, L., 2009. Global change and relative sea 643 level rise at Venice: what impact in term of flooding. Climate Dynamics, 644 doi:10.1007/s00382-009-0617-5. 
645 Castelletto, N., Ferronato, M., Gambolati, G., Putti, M., Teatini, P., 2008. Can Venice

646 be raised by pumping water underground? A pilot project to help decide. Water 647 Resources Research, 44, W01408, doi:10.1029/2007WR006177.

648 Castelletto, N., Ferronato, M., Gambolati, G., Janna, C., Teatini, P., Marzorati, D., 649 Cairo, E., Colombo, D., Ferretti, A., Bagliani, A., Mantica, S., 2010. 3D 650 geomechanics in UGS projects. A comprehensive study in northern Italy. In: Proc. 651 44th U.S. Rock Mechanics Symposium. American Rock Mechanics Association, in 652 press.

653 Chen, C.T., Hu, J.T., Lu, C.Y., Lee, J.C., Chan, Y.C., 2007. Thirty-year land elevation 654 change from subsidence to uplift following the termination of groundwater pumping 655 and its geological implications in the Metropolitan Taipei Basin, Northern Taiwan. 656 Engineering Geology 95, 30-47.

657 Ciavola, P., 2005. The new Beach Management System at Lido Adriano, Ravenna, 658 Italy. Footprints - ShoreGro Newsletter 3, 5-6.

659 Colazas, X.C., Olson, L.J., 1983. Subsidence monitoring methods and beach mark 660 elevation response to water injection, Wilmington oil field, Long Beach, California. 661 In Donaldson, E.C., and van Domselaar, H., (Eds.), Proceedings of 1982 Forum on 662 Subsidence due to Fluid Withdrawals, U.S. Government Printing Office, pp. 121$663 \quad 132$.

664 Colesanti, C., Ferretti, A., Novali, F., Prati, C., Rocca, F., 2003. SAR monitoring of 665 progressive and seasonal round deformation using the Permanent Scatterers 666 technique. IEEE Transactions of Geoscience and Remote Sensing 41, 1685-1701.

667 Collins, P.M., 2007. Geomechanical effects on the SAGD process. SPE Reservoir $668 \quad$ Evaluation \& Engineering 10(4), 367-375.

669 Comerlati, A., Ferronato, M., Gambolati, G., Putti M., Teatini, P., 2003. Can $\mathrm{CO}_{2}$ help 670 save Venice from the sea? EOS Transaction AGU, 84(49), 546-553. 
671 Comerlati, A., Ferronato, M., Gambolati, G., Putti M., Teatini, P., 2004. Saving Venice

672 by seawater. Journal of Geophysical Research, 109(F3), doi: 10.1029/2004JF000119.

673 Coussy, O., 1995. Mechanics of Porous Continua. Wiley, New York (NY).

674 de Koning, J., de Pater, H., Walters, D., Maxwell, S., 2008. Geomechanics for 675 interpreting SAGD monitoring using micro-seismicity and surface tiltmeters. Paper 676 SPE/PS/CHOA 117688, Int. Thermal Operations and Heavy Oil Symp., Calgary, 677 Alberta, Canada, 20-23 Oct. 2008, 20pp.

678 Donaldson, E.C., 1964. Surface disposal of industrial wastes in the United States. 679 Technical Report, U.S. Bureau of Mones, Washington D.C..

680 Du, J., Brissenden, S.J., McGillivray, P., Bourne, S., Hofstra, P., Davis, E.J., 681 Roadarmel, W.H., Wolhart, S.L., Marsic, S., Gusek, R., Wright, C.A., 2005. 682 Mapping reservoir volume changes during cyclic steam stimulation using tiltmeter683 based surface-deformation measurements. Paper SPE/PS-CIM/CHOA 97848 684 PS2005-384, 2005 Int. Thermal Operations and Heavy Oil Symposium, Calgary, 1-3 $685 \quad$ November, 2005, 12pp.

686 Dusseault, M.B., Rothenburg, L., 1988. Shear dilatancy and permeability enhancement 687 in oil sands. In: Proceedings of the 4th UNITAR Conference Heavy Crude and Tar 688 Sand, vol. 3, pp. 55-66.

689 ENI S.p.A., 2007. Progetto sperimentale Angelina Pressure Maintenace - Rapporto 690 trimestrale alla Provincia di Ravenna, Marzo 2007. ENI S.p.A. - Divisione E\&P 691 Report, 12 pp. (in Italian)

692 Ferretti, A., Prati, C., Rocca, F., 2001. Permanent scatterers in SAR interferometry. 693 IEEE Transactions on Geoscience and Remote Sensing 39, 8-20.

694 Ferretti, A., Novali, F., Bürgmann, R., Hilley, G., Prati, C., 2004. InSAR Permanent 695 Scatterer analysis reveals ups and downs in San Francisco Bay area. EOS 696 Transactions of the American Geophysical Union 85, 317-324. 
697 Ferronato, M., Gambolati, G., Teatini, P., 2003. Unloading-reloading uniaxial

698 compressibility of deep reservoirs by marker measurements. In S. Stiros and S.

699 Pytharouli (Eds.), Proceedings of 11th International Symposium on Deformation

700 Measurements. Geodesy and Geodetic Applications Laboratory, Patras University, $701 \quad$ pp. $341-346$.

702 Ferronato, M., Gambolati, G., Putti, M., Teatini, P., 2008. A pilot project using seawater 703 to uplift Venice anthropogenically. EOS Transaction AGU, 89(15), 152.

704 Galloway, D.L., Hudnut, K.W., Ingebritsen, S.E., Phillips, S.P., Peltzer, G., Rogez, F., 705 Rosen, P.A., 1998. Detection of aquifer system compaction and land subsidence 706 using interferometric synthetic aperture radar, Antelope Valley, Mojave Desert, 707 California. Water Resources Research 34, 2573-2585.

708 Galloway, D.L., Hoffmann, J., 2007. The application of satellite differential SAR 709 interferometry-derived ground displacements in hydrogeology. Hydrogeology 710 Journal $15,133-154$.

711 Gambolati, G., Teatini, P., Tomasi, L., 1998. Convenzione tra il Ministero 712 dell'Ambiente e l'Università degli Studi di Padova per la realizzazione di un modello 713 matematico previsivo degli eventuali effetti di subsidenza connessi alla coltivazione 714 di giacimenti di idrocarburi in Alto Adriatico. Technical Report, DMMMSA, 715 University of Padova, 179 pp. (in Italian)

716 Gambolati, G., Teatini, P., Tomasi, L., Gonella, M., 1999. Coastline regression of the 717 Romagna Region, Italy, due to natural and anthropogenic land subsidence and sea 718 level rise. Water Resources Research 35, 163-184.

719 Gambolati, G., Teatini, P., Ferronato, M., 2005. Anthropogenic land subsidence. In 720 Anderson, M.G., (Ed.), The Encyclopedia of Hydrological Sciences. John Wiley \& 721 Sons, London, pp. 2443-2460. 
722 Hoffmann, J., Zebker, H.A., Galloway, D.L., Amelung, F., 2001. Seasonal subsidence

723 and rebound in Las Vegas Valley, Nevada, observed by synthetic aperture radar

724 interferometry. Water Resources Research 37, 1551-1566.

725 Hoffmann, J., Zebker, H.A., 2003. Prospecting or horizontal surface displacements in

726 Antelope Valley, California, using satellite radar interferometry. Journal of

727 Geophysical Research 108 (F1), doi:10.1029/2003JF000055.

728 Ingebritsen, S.E., Jones, D.R., 1999. Santa Clara Valley, California. In: Galloway, D.L., 729 et al. (Eds.), Land Subsidence in the United States, USGS Circular 1182, pp. 15-22.

730 International Gas Union, 2003. Underground Gas Storage Data Bank, 731 http://www.igu.org/html/wgc2003/WGC_pdffiles/data/IGU/IGU-UGS-World-Data-

$732 \quad$ Bank.mdb

733 Jahr, T., Jentzsch, G., Letz, H., Sauter, M., 2005. Fluid injection and surface 734 deformation at the KTB location: modelling of expected tilt effects. Geofluids 5, 2073527.

736 Jahr, T., Letz, H., Jentzsch, G., 2006. Monitoring fluid induced deformation of the 737 earth's crust: a large scale experiment at the KTB location, Germany. Journal of $738 \quad$ Geodynamics 41, 190-197.

739 Jahr, T., Jentzsch, G., Gebauer, A., Lau, T., 2008. Deformation, seismicity, and fluids:

740 results of the 2004/2005 water injection experiment at the KTB, Germany. Journal of $741 \quad$ Geophysical Research 113 (B11430), doi:10.1029/2008JB005610.

742 Kosloff D., Scott R.F., Scranton J., 1980a. Finite element simulation of Wilmington oil 743 field subsidence: I. Linear modelling. Tectonophysics 65, 339-368.

744 Kosloff D., Scott R.F., Scranton J., 1980b. Finite element simulation of Wilmington oil 745 field subsidence: II. Nonlinear modelling. Tectonophysics 70, 159-183.

746 Kumpel, H.J., Erzinger, J., Shapiro, S., 2006. Two massive hydraulic tests completed in 747 deep KTB borehole. Scientific Drilling Journal 3, 40-42. 
748 Law., J., 1950. Interrelations between earth movements. Report to the Harbor

749 Commissioners, City of Long Beach, p. 94.

750 Las Vegas Valley Water District, 2005. 2005 Artificial recharge annual report. Las

$751 \quad$ Vegas Valley Water District Unpublished Report, 150 pp.

752 Mayuga, M.N., Allen, D.R., 1970. Subsidence in the Wilmington Oil Field, Long

753 Beach, California, USA. In Tjson, L.J., (Ed.), Land Subsidence, Proceedings of the

754 Tokyo Symposium 1969. IAHS Publication no. 88, pp. 66-79.

755 McGillivray, P.R., Brissenden, S., Bourne, S., Maron, K., Bakker, P., 2006. Making

756 sense of the geomechanical impact on the heavy-oil extraction process at Peace River

757 based on quantitalive analysis and modeling. Paper SPE 102876, 2006 SPE Annual

758 Tech. Conf., San Antonio, Texas, USA, 24-27 Sept. 2006, 5 pp.

759 Metropolitan Water District of Southern California, 2007. Groundwater Assessment $760 \quad$ Study. Report Number 1308.

761 O’Rourke, J.C., Begley, A.G., Boyle, H.A., Yee, C.T., Chambers, J.I., Luhning, R.W., 762 1997. UTF Project Status Update May 1997. Journal of Petroleum Technology 38(9), $763 \quad 44-54$.

764 Otott Jr., G.E., Clarke, D.D., 1996. History of the Wilmington field - 1986-1996. In:

765 AAPG Pacific Section, Old Oil Fields and New Life: A Visit to the Giants of the Los

766 Angeles Basin, pp. 17-22.

767 Petro-Canada, 2008. MacKay River Performance Presentation Approval No. 8668.

768 Petro-Canada report to ERCB, accessible at:

769 http://www.ercb.ca/docs/products/osprogressreports/2008/2008AthabascaPetroCanad $770 \quad$ aMacKayRiverSAGD8668.zip

771 Piccini, M.F., Gonella, M., Teatini, P., Gabbianelli, G., 2006. Modeling groundwater

772 response to beach dewatering at Ravenna shoreline. In A. Micallef et al. (Eds.), 773 Proceedings of 2nd International Conference on Management of Coastal Recreational 
774

775

776

777

778

779

780

781

782

783

784

785

786

787

788

789

790

791

792

793

794

795

796

797

798

799

Resources - Beaches, Yachting and Coastal Ecotourism. Euro Mediterranean Centre on Insular Coastal Dynamics Publisher, University of Malta, pp. 169-178.

Poland, J.F., Ireland R. L. (1988). Land subsidence in the Santa Clara valley, California, as of 1982, mechanics of aquifer systems, U.S. Geol. Surv., Prof. Pap., 497-F, 61 pp.

Rintoul, W., 1981. The case of the disappearing land. In: Drilling Ahead: Tapping California’s Richest Oil Fields. Valley Publ., Santa Cruz (CA), pp. 116-137.

Schmidt, D.A., Bürgmann, R., 2003. Time dependent land uplift and subsidence in the Santa Clara Valley, California, from a large InSAR data set. Journal of Geophysical Research 108 (B9), doi:10.1029/2002JB002267.

Schroot, B.M, Fokker, P.A., Lutgert, J.E., van der Meer, B.G.H., Orlic, B., Scheffers, B.C., 2005. Subsidence induced by gas production: an integrated approach. In: Barends, F.B.J. et al. (Eds.), Land Subsidence-Special Volume (Proceedings of $7^{\text {th }}$ International Symposium on Land Subsidence). Millpress Science Publishers, Rotterdam (The Netherlands), pp. 121-136.

Settari, A., Kry, P.R., Yeh, C.T., 1989. Coupling of fluid flow and soil behavior to model injection into uncemented oil sands. Journal of Canadian Petroleum Technology 28, 81-92.

Settari, A., Ito, Y., Fukushima, N., Vaziri, H., 1993. Geotechnical aspects of recovery processes in oil sands. Canadian Geotechnical Journal 30, 22-33.

Sreng, S., Li, L., Sugiyama, H., Kusaka, T., Saitoh, M., 2009. Upheaval phenomenon in clay ground induced by rising groundwater level. In H.I. Ling et al. (Eds.), Poromechanics IV, to appear.

Stancliffe, R.P.W., van der Kooij, M.W.A.. 2001. The use of satellite-based radar interferometry to monitor production activity at the Cold Lake heavy oil field, Alberta, Canada. The American Association of Petroleum Geologists Bulletin 85(5), 781-793. 
800 Suncor, 2008. 2008 ERCB Annual Review Suncor Firebag. Suncor Report to ERCB,

801 accessible at:

802 http://www.ercb.ca/docs/products/osprogressreports/2008/2008AthabascaSuncorFire 803 bagSAGD8870.pdf

804 Teatini, P., Gambolati, G., Tomasi, L., Putti, M., 1998. Simulation of land subsidence 805 due to gas production at Ravenna coastline. In G. Gambolati (Ed.), CENAS, 806 Coastline Evolution of the Upper Adriatic Sea due to Sea Level Rise and Natural and 807 Anthropogenic Land Subsidence. Kluwer Academic Publisher, Water Science and 808 Technology Library No. 28, pp. 133-150.

809 Teatini, P., Baù, D., Gambolati, G., 2000. Water-gas dynamics and coastal land 810 subsidence over Chioggia Mare field, Northern Adriatic sea. Hydrogeology Journal $811 \quad 8,462-479$.

812 Teatini, P., Gambolati, G., Castelletto, N., Ferronato, M., Janna, C., Marzorati, D.,

813 Cairo, E., Colombo, D., Ferretti, A., Bagliani, A., Bottazzi, F., Rocca, F., 2010.

814 Monitoring and modelling 3D ground movements induced by seasonal gas storage in 815 deep reservoirs. In: EISOLS 2010, Proceedings of the 8th Int. Symp. on Land 816 Subsidence. IAHR, in press.

817 United States Environmental Protection Agency, 2002. Technical program overview: 818 Underground injection control regulation. Tech. Rep. EPA 816-R-02-025, 81 pp., 819 Washington, D. C.

820 Vasco, D. W., Rucci, A., Ferretti, A., Novali, F., Bissell, R. C., Ringrose, P. S., 821 Mathieson, A. S., Wright, I. W., 2010. Satellite-based measurements of surface 822 deformation reveal fluid flow associated with the geological storage of carbon 823 dioxide. Geophysical Research Letters, 37, L03303, doi:10.1029/2009GL041544.

824 Vesiĉ, A.S., Clough, G.W., 1968. Behaviour of granular soils under high stresses. 825 ASCE, Soil Mechanics and Foundation Division, pp. 661-687. 
826 Walters, D.A., 2007. Coupled geomechanical and reservoir simulation of the UTF

827 Phase B pilot project. Final Report to the Joint Industry Consortium, TAURUS

828 Reservoir Solutions Ltd., January 2007.

829 Wang, G., Kry, P.R., 1997. Surface heave due to fluid and steam injection. In:

830 Proceedings of $48^{\text {th }}$ Annual Technical Meeting of the Petroleum Society, Calgary,

$831 \quad$ Alberta (CA), paper 97-10, 18 pp.

832 Watson, K.M., Bock, Y., Sandwell, D.T., 2002. Satellite interferometric observations of 833 displacements associated with seasonal groundwater in the Los Angeles basin. 834 Journal of Geophysical Research 107 (B4), doi: 10.1029/2001JB000470.

835 Wong, R.C.K., Lau, J., 2008. Surface heave induced by steam stimulation in oil sands 836 reservoirs. Journal of Canadian Petroleum Technology 47(1), 13-17.

837 Wu, C.M., Groundwater depletion and land subsidence in Taipei Basin. In Rodda, J.C. 838 (Ed.), Land Subsidence, Proceedings of 2nd International Symposium on Land 839 Subsidence. IAHS Publication No. 121, pp. 389-398.

840 Yamamoto, S., 1984. Case history no. 9.4: Tokyo, Japan. In Poland, J.F. (Ed.), 841 Guidebook to Studies of Land Subsidence Due to Ground-water Withdrawal. U.N. 842 Educational Science and Cultural Organ., Paris, pp. 175-184.

843 Yamamoto, S., 1995. Recent trend of land subsidence in Japan. In F.B.J. Barends et al. 844 (Eds.), Land Subsidence, Proceedings of 5th International Symposium on Land 845 Subsidence. IAHS Publication No. 234, pp. 487-492.

846 Yee, C.-T., Stroich, A., 2004. Flue gas injection into a mature SAGD steam chamber at 847 the Dover Project (Formerly UTF). Journal of Canadian Petroleum Technology $848 \quad 43(1), 54-61$.

849 


\section{FIGURE CAPTIONS}

850 Figure 1. Mohr-Coulomb circles. When the pore pressure $p$ increases because of fluid

851 injection, the circles move leftward and may achieve the limiting yield surface or

852 friction line $\tau=c+\sigma_{n} \tan \phi$ where $\sigma$ and $\tau$ are the normal and shear stress, respectively,

$853 c$ is cohesion and $\phi$ the friction angle. $\tau_{\mathrm{m}}$ and $\tau \mathrm{m}^{*}$ are the current largest and maximum

854 allowable shear stress, respectively, $\sigma_{1}$ and $\sigma_{3}$ the maximum and minimum principal 855 stress, respectively.

856 Figure 2. (a) Differential heave in 3 pads of the Cold Lake CSS during one steam 857 injection period (modifed from Wong and Kry, 1997). The upper figure is the total 858 heave at the beginning of the period, and the lower figure is the incremental heave between the beginning and the end of the one month period. (b) Deformations over a

860 time period of 86 days (August 5, 1996 - November 1, 1996) measured by InSAR in

861 Cold Lake CSS project (adapted from Stancliffe and van der Kooij, 2001). Uplift is 862 positive.

863 Figure 3. Heave (a) over a one-year period and (b) from April 26, 2005 to June 5, 2005

864 calculated by tiltmeter data in the Shell Canada Peace River CSS project (modified from

865 Du et al., 2005).

866 Figure 4. Distribution of heave with depth from September 1993 to April 1994 at the

867 UTF BE2 extensometer site (adapted from Collins, 2007).

868 Figure 5. Heave (a) in the MacKay River SAGD project from December 2002 to

869 December 2007. The leveling monuments used to map the ground displacements are

870 shown. (b) Heave development in time along the cross section $\mathrm{AB}$ traced in (a)

871 (modified from Petro-Canada, 2008).

872 Figure 6. Vertical land displacement recorded by Differential InSAR in the Santa Clara

873 Valley, California. (a) Cumulative uplift measured from September 1992 to October 874 1999; (b) seasonal upheaval measured from August 1998 to March 1999. The bottom 
875 insets shows the time series at two points illustrating the seasonal vs. long-term

876 deformation pattern partitioned by the Silver Creek (modified after Schmidt and

877 Bürgmann, 2003; Galloway and Hoffmann, 2007).

878 Figure 7. (a) Ground displacement in the Santa Ana Basin, California, detected by

879 Differential InSAR from July 1998 to January 1999. (b) Uplift behaviour along the A-

880 A' cross-section traced in (a) (modified after Bawden et al., 2001).

881 Figure 8. Velocity map for the northwest portion of Las Vegas Valley, Nevada,

882 obtained by Persistent Scatterer InSAR from ENVISAT data between April 2003 and

883 May 2005. The contour lines of the water-level change $(\mathrm{m})$ recorded in the same 884 interval are shown. The inset on the right shows the time series of the vertical 885 displacement for the persistent scatterer indicated on the map (modified after Bell et al., 886 2008).

887 Figure 9. Mean land vertical velocity above the Krechba field, Algeria, as detected by 888 the analysis of PSInSAR data in the period 2003-2007 (modified after Vasco et al., 889 2010).

890 Figure 10. Vertical displacements $(\mathrm{mm})$ vs. time for a few pixels monitored by InSAR 891 located above the Lombardia field, northern Italy.

892 Figure 11. Land vertical displacements above the Lombardia field between: (a) 893 November 2005 and April 2006; (b) April 2006 and November 2006. The maps are 894 obtained with a kriging interpolation of InSAR data. The reservoir outline is also 895 shown.

896 Figure 12. (a) Land uplift (inches) at Long Beach, California, from 1958 to1975 as a 897 result of elastic unloading caused by repressurization of the producing field blocks 898 (modified after Kosloff et al., 1980b). (b) Increase in elevation (feet) measured at a 899 leveling benchmark above a eastern block of the Wilmington field (modified after 900 Colazas and Olson, 1983). 
901 Figure 13. Ground upheaval in Tokyo: (a) groundwater level and vertical displacement

902 over period 1962-2005; (b) cumulative upheaval distribution in the urban area over the 903 period 1991-2005 (modified after Sreng et al., 2009).

904 Figure 14. (a) Map of land uplift in the Taipei basin from 1989 and 2003 as obtained by

905 interpolation of the leveling records. (b) Land upheaval rate over the period 1989-1994

906 (modified after Chen et al., 2007).

907 Figure 15. Fluid pore pressure change $\left(10^{-1} \mathrm{MPa}\right.$, above $)$ and anthropogenic land 908 subsidence (cm, below) at the end of the Chioggia Mare gas field production life as 909 predicted with the aid of numerical models: (a) and (c) without, (b) and (d) with the 910 seawater injection wells. Negative values denote pressure decline, positive values 911 pressure increase. The outline of the Chioggia Mare reservoir is also shown (modified 912 after Teatini et al., 2000).

913 Figure 16. Anthropogenic land subsidence and land heave in Chioggia as predicted

914 with the aid of numerical models without (solid lines) and with (dashed lines) seawater

915 injection wells for the various hydro-geo-mechanical scenarios addressed by Gambolati 916 et al. (1998).

917 Figure 17. (a) Location of the Angela-Angelina gas field along the Northern Adriatic 918 coastline, Italy. The trace of the reservoir is highlighted in red. (b) Representation of the 919 three-phase ENI-E\&P injection programme "Angela Pressure Maintenance". (c) 920 Cumulative volume of water injected from March 2003 to April 2007 in the ENI-E\&P 921 injection programme "Angela Pressure Maintenance".

922 Figure 18. Results from the finite element interpretation and reconstruction of the 923 tiltmeter measurements: (a) land uplift; (b) tilts at the land surface (modified after Jahr 924 et al., 2008).

925 Figure 19. Ratio $r$ between virgin and second cycle elastic compressibility versus depth 926 as derived from the case studies addressed in the present paper (1: Santa Clara Valley, 
927 California; 2: Las Vegas Valley, Nevada; 3: Lombardia field, Italy; 4: Wilmington,

928 California; 5: Taipei, Taiwan; and 6: Ravenna, Italy). 


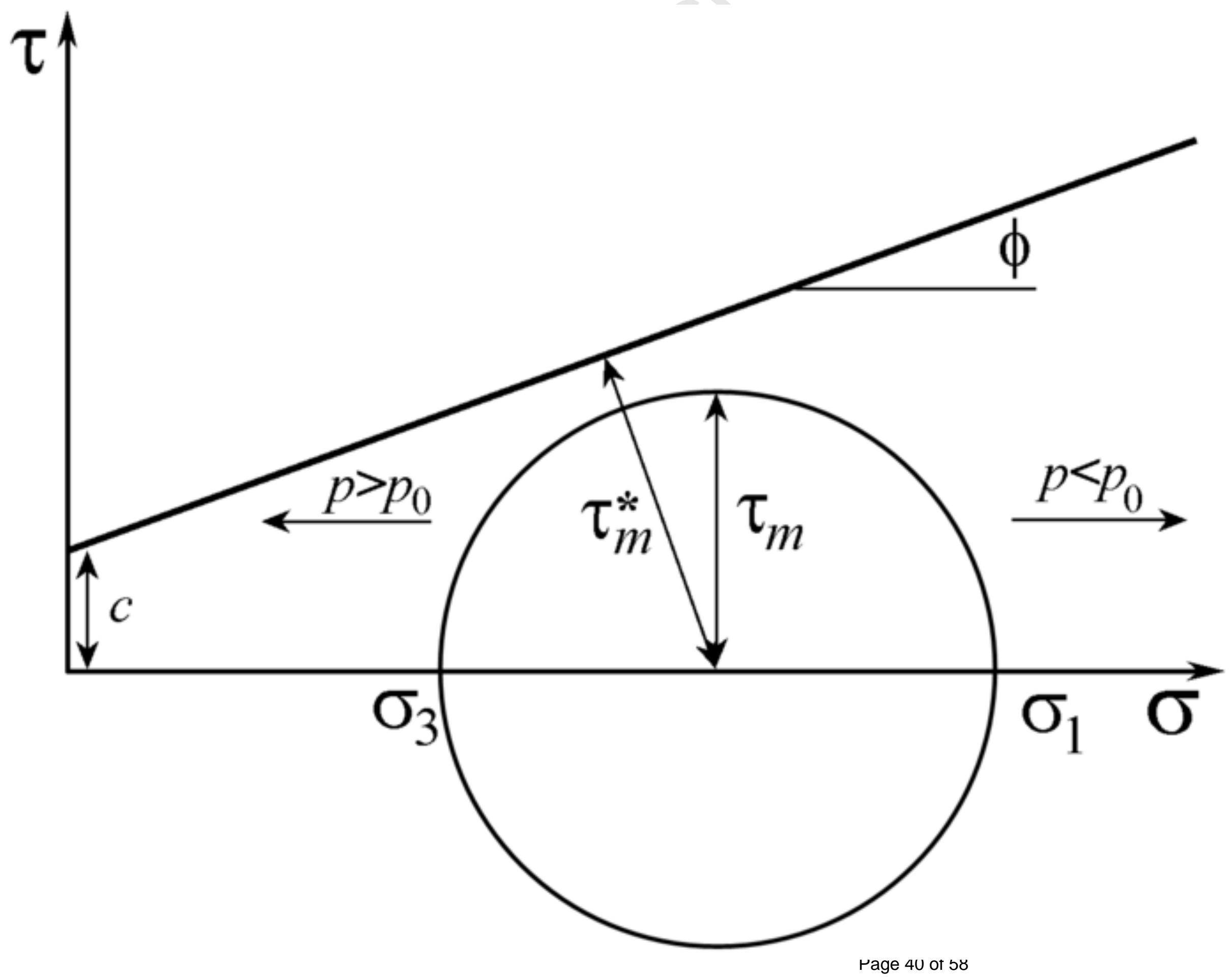

rage 40 or b૪ 


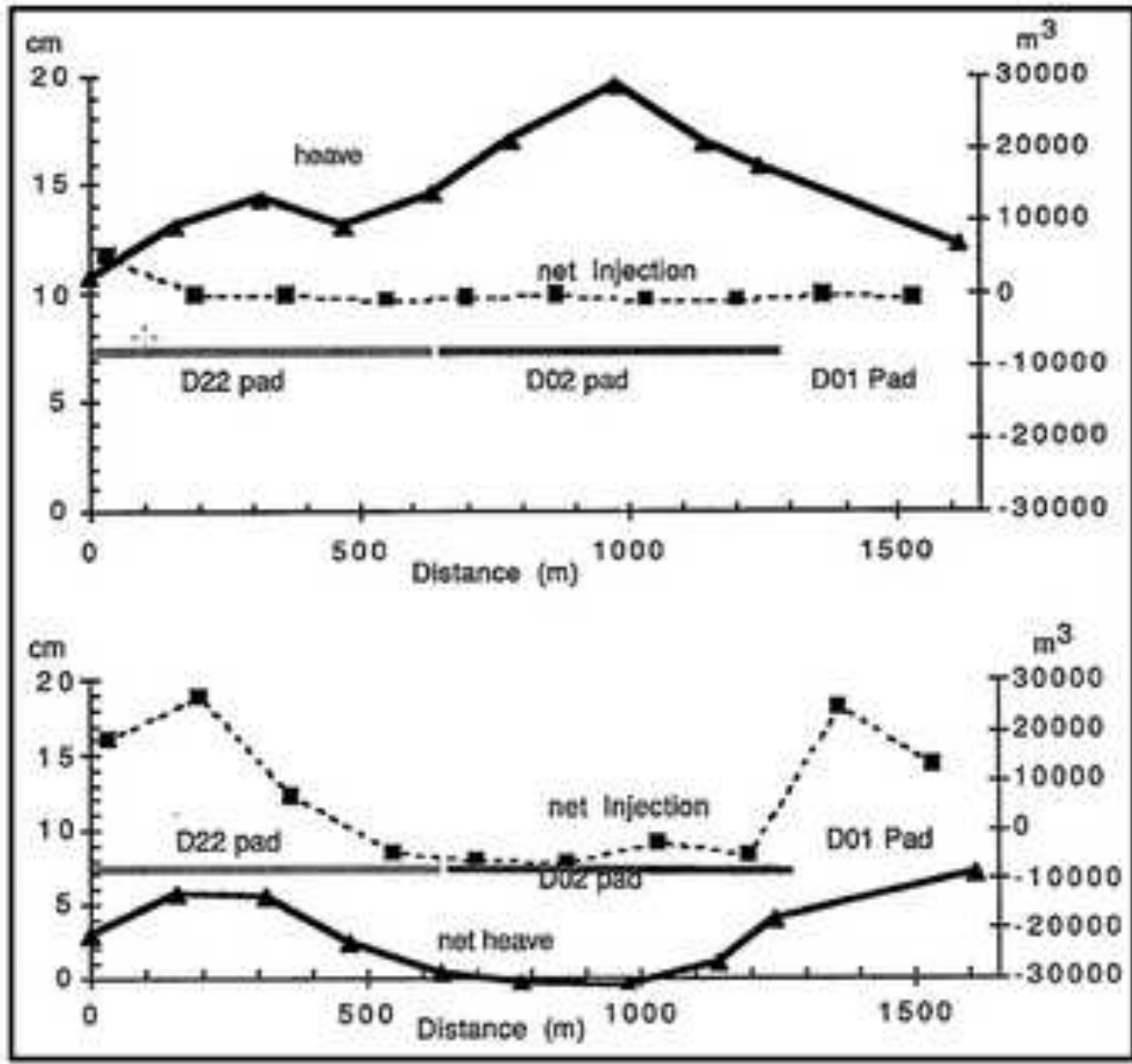

(a)
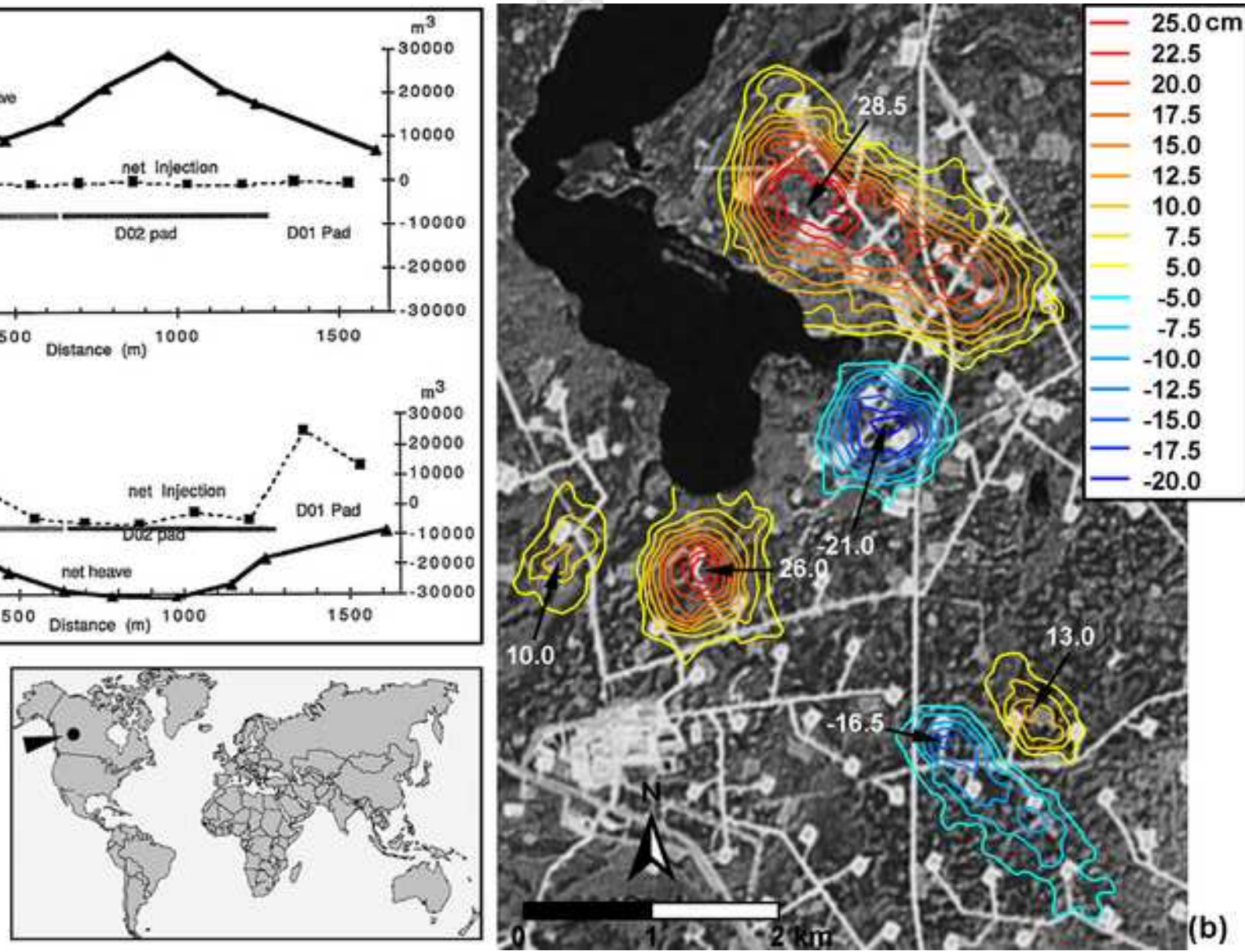

Page 41 of 58 

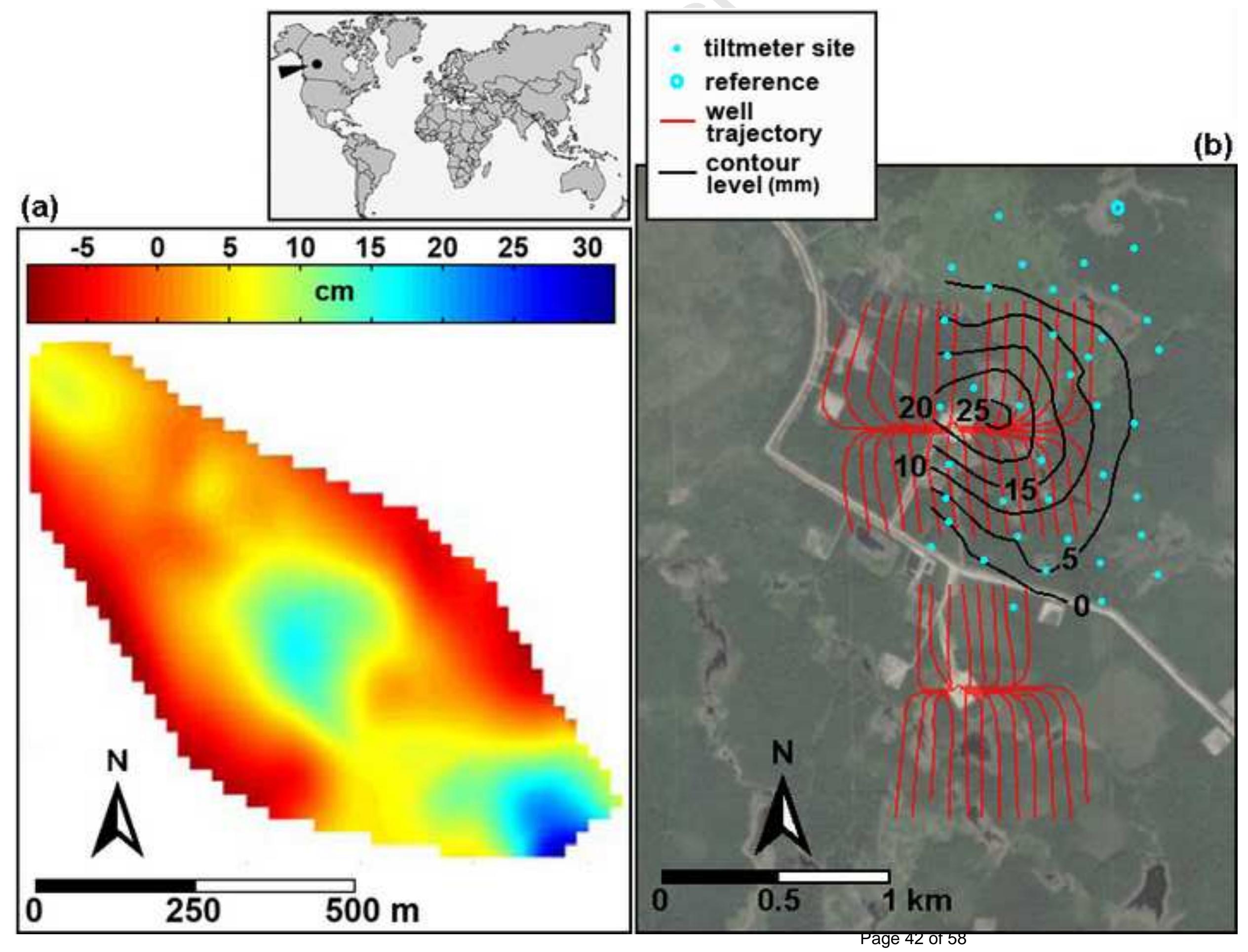


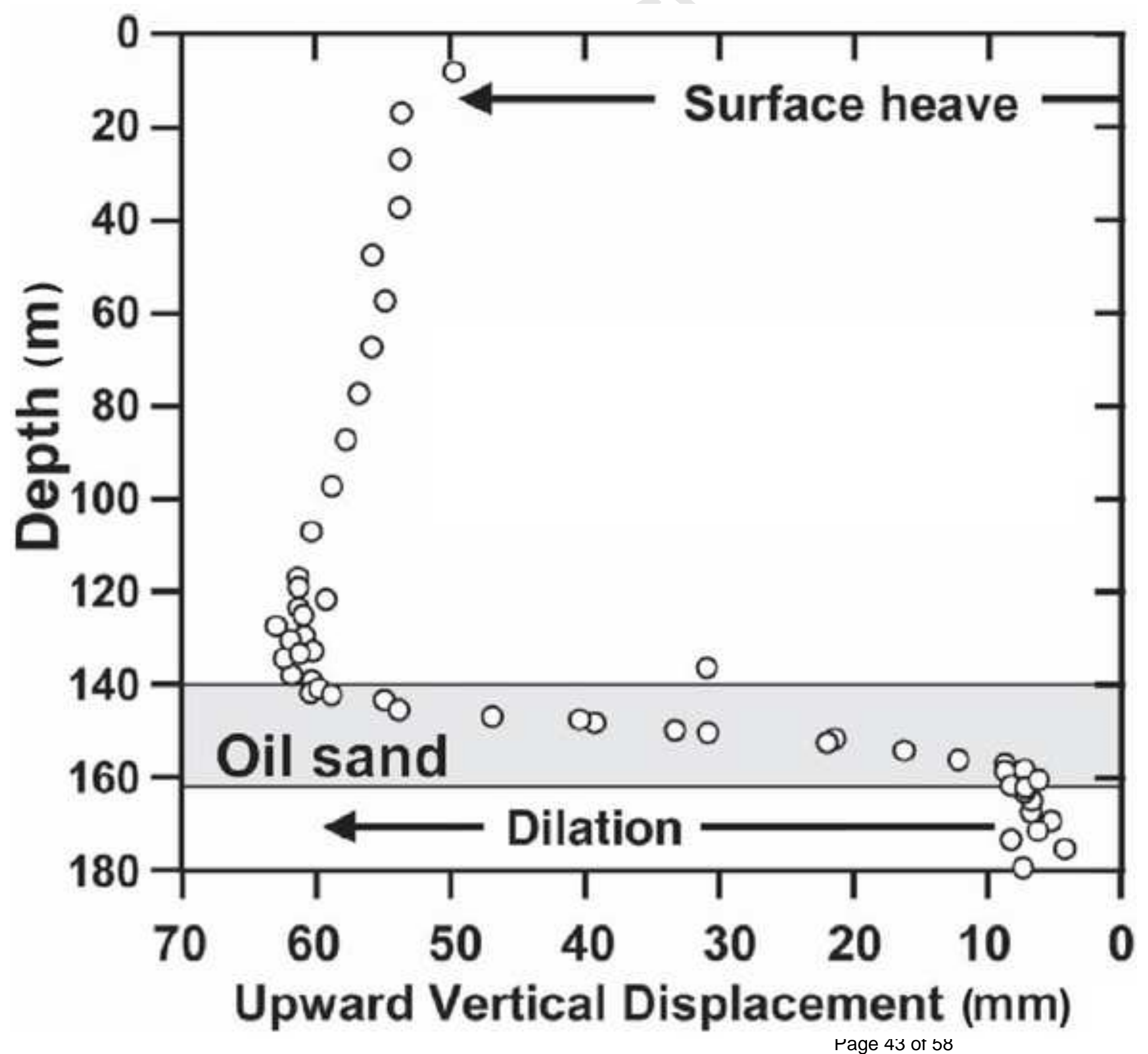

rage 43 or bל 

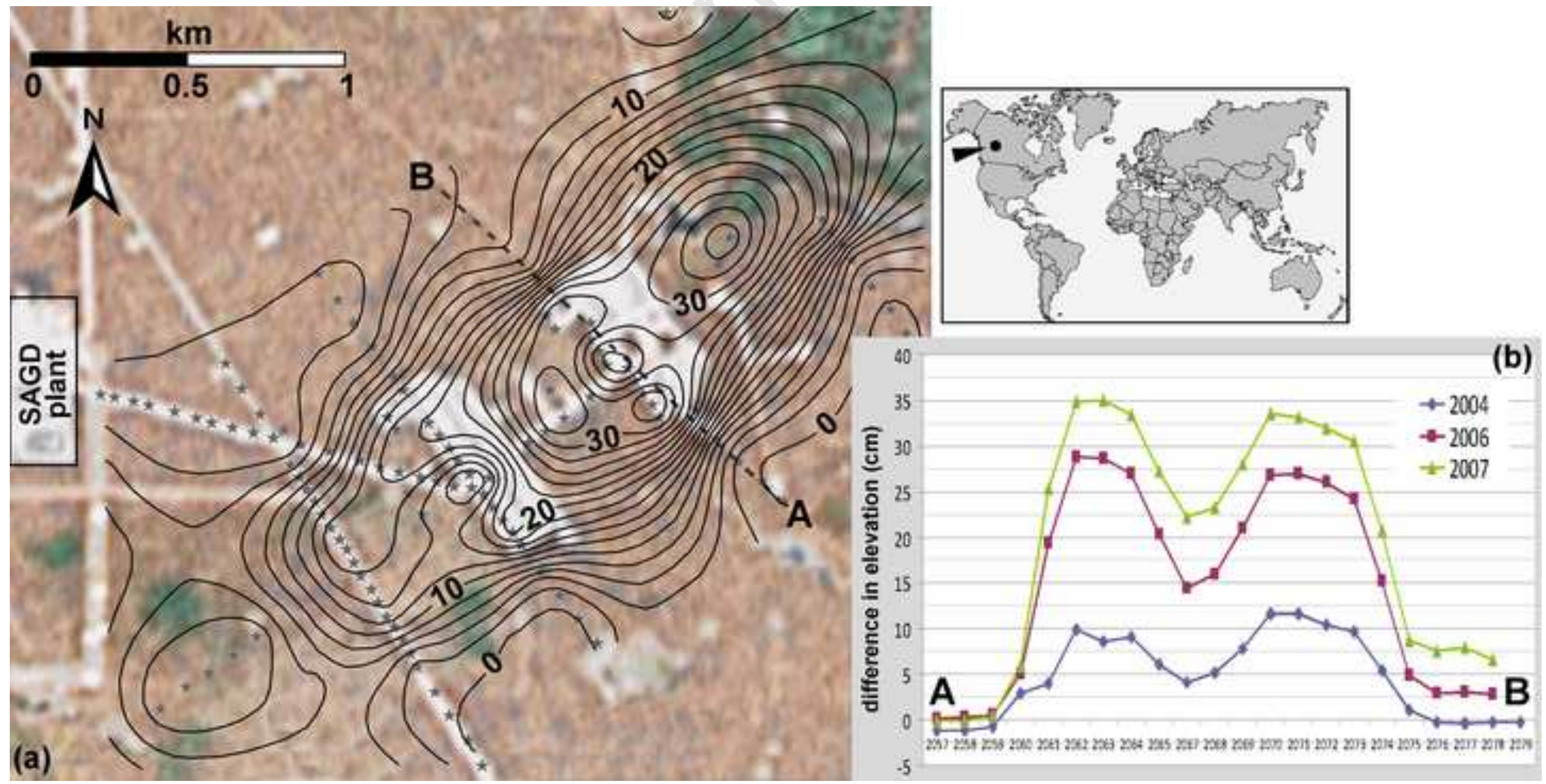

Page 44 of 58 


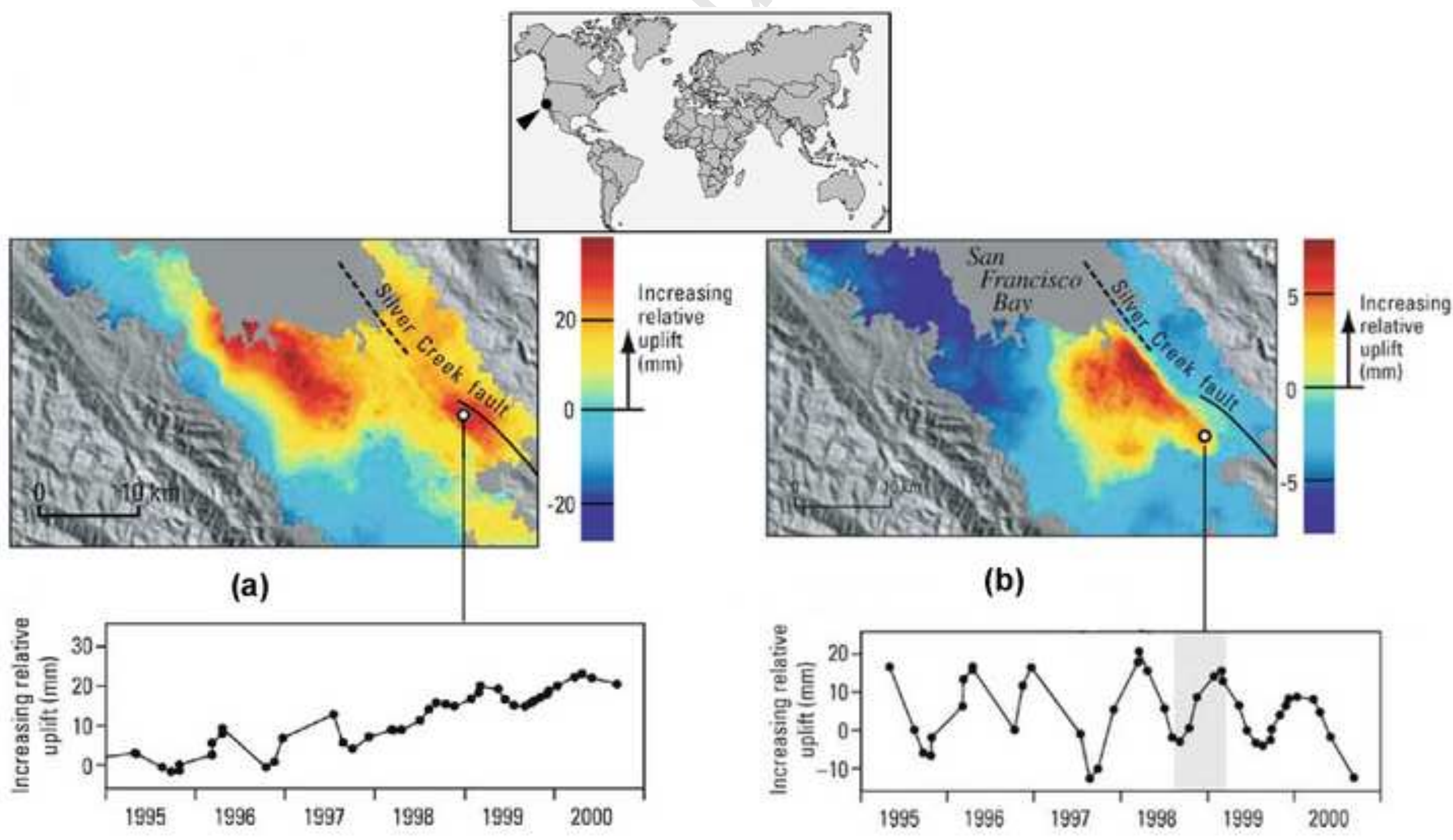




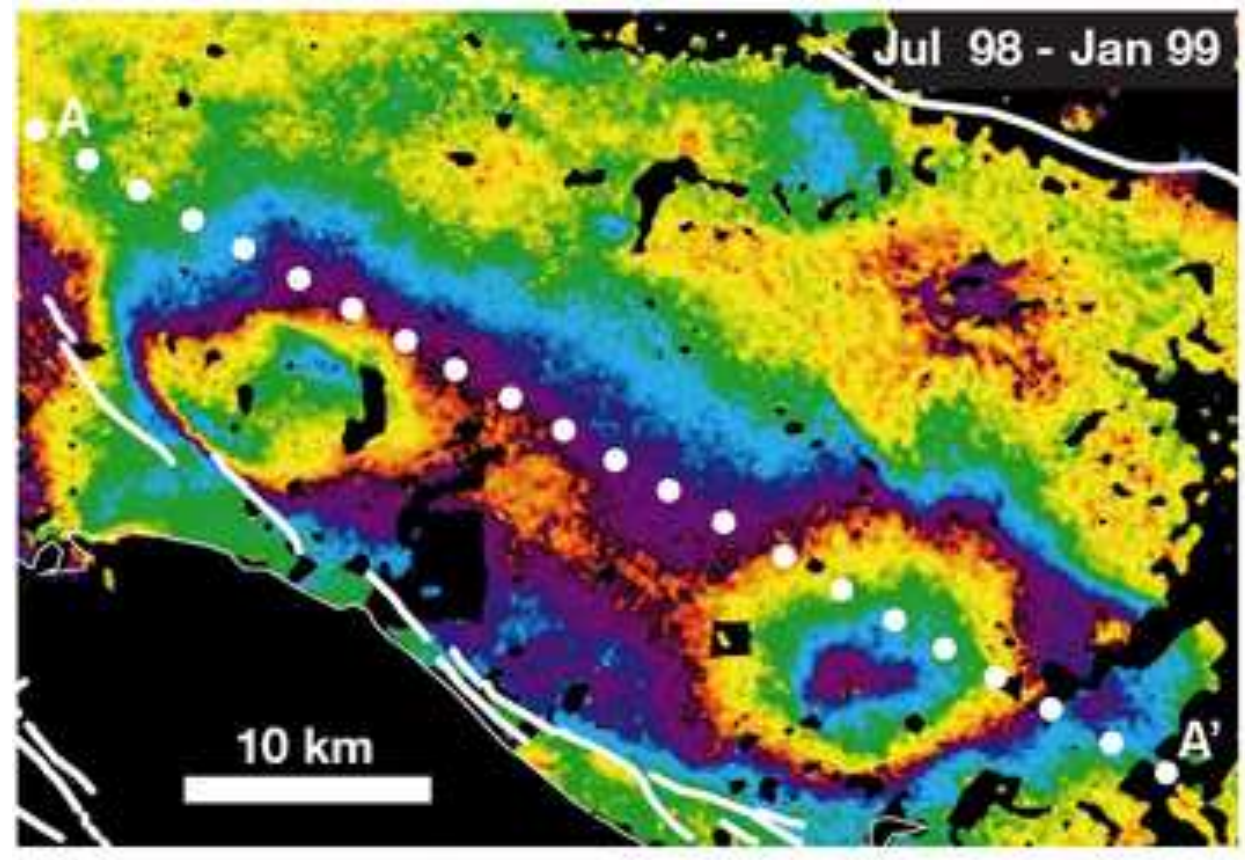

(a)
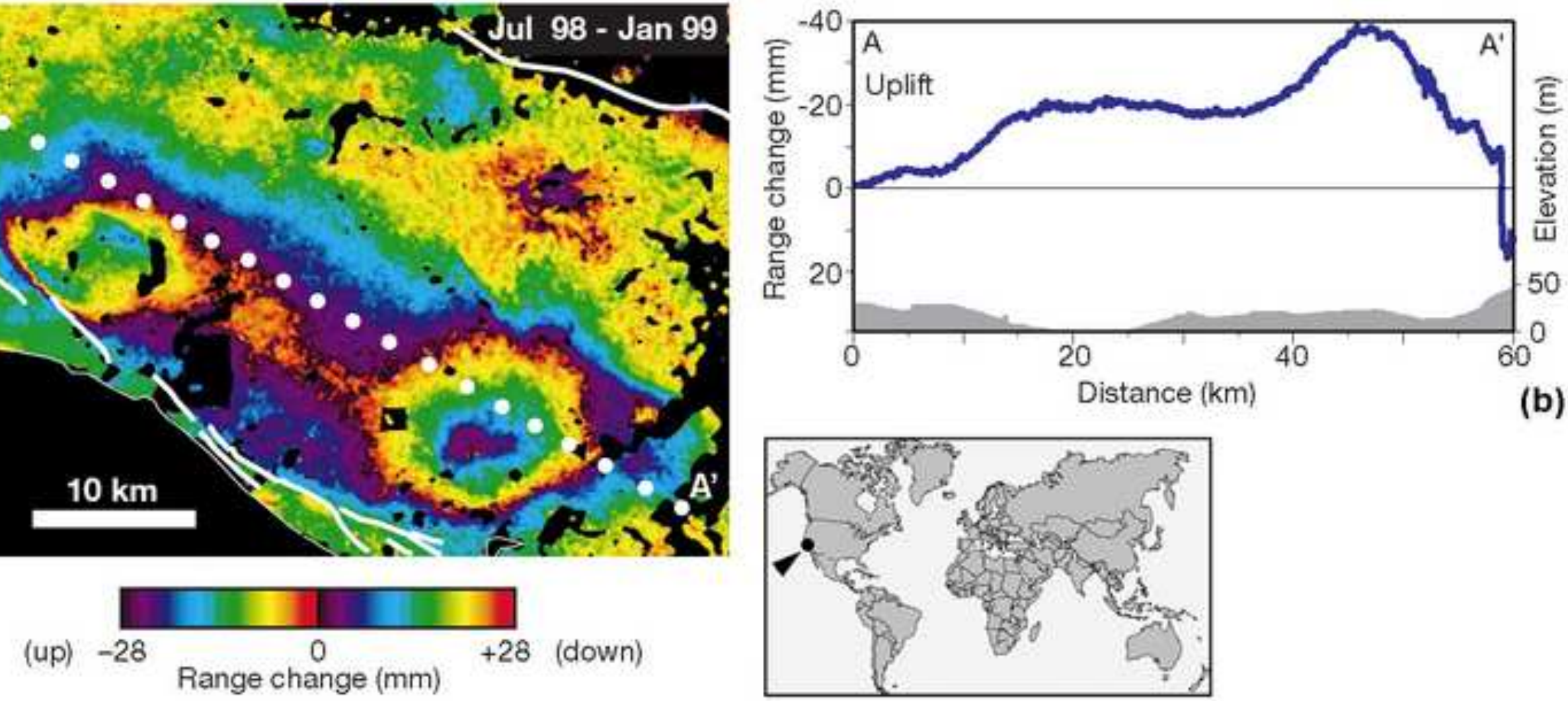


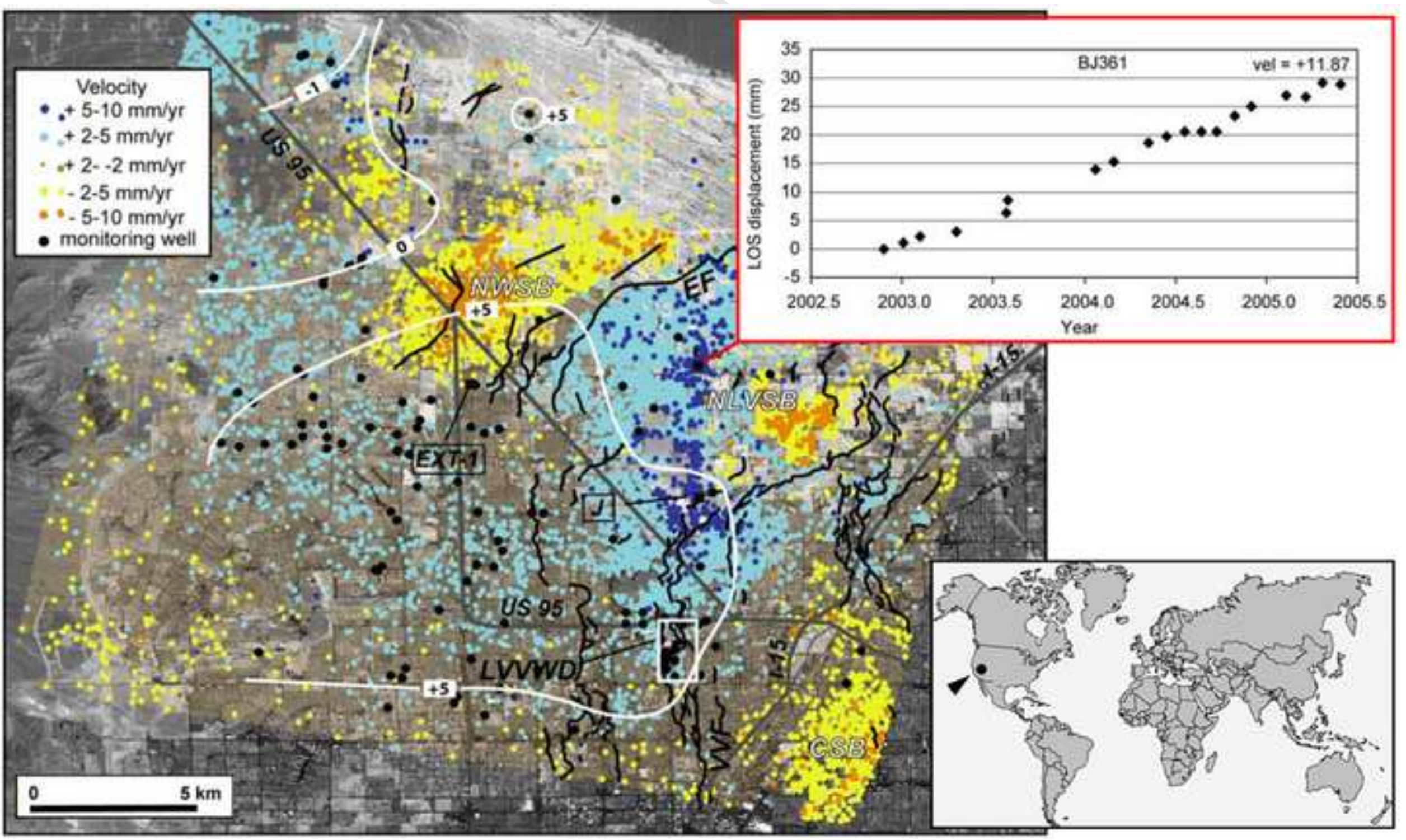




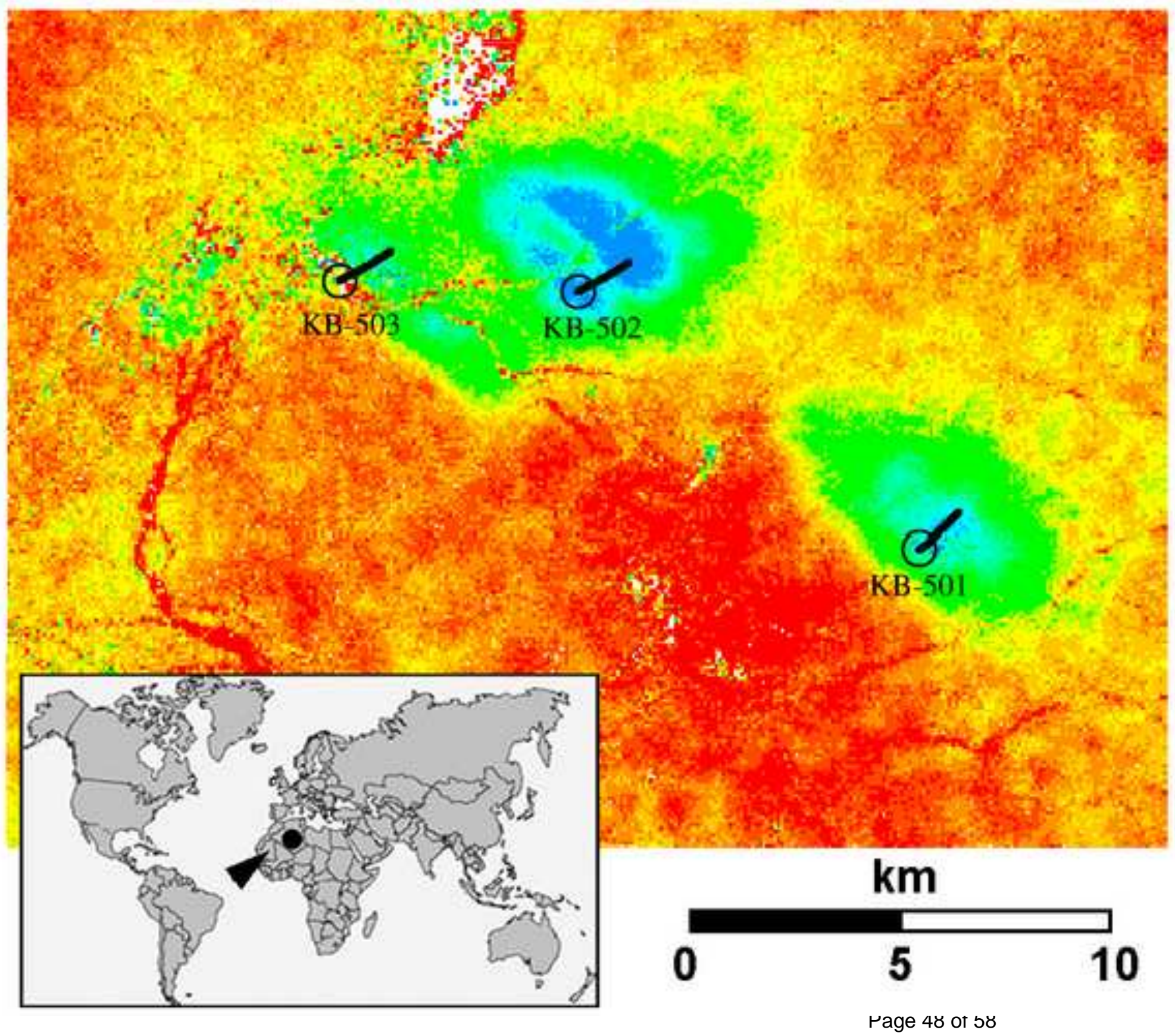

rage 48 oा ๖૪

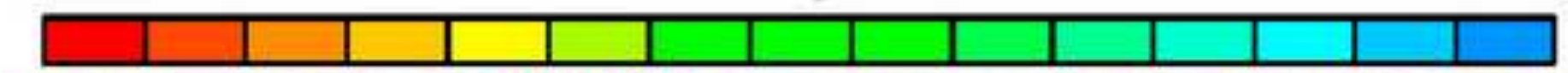

Page 480158 


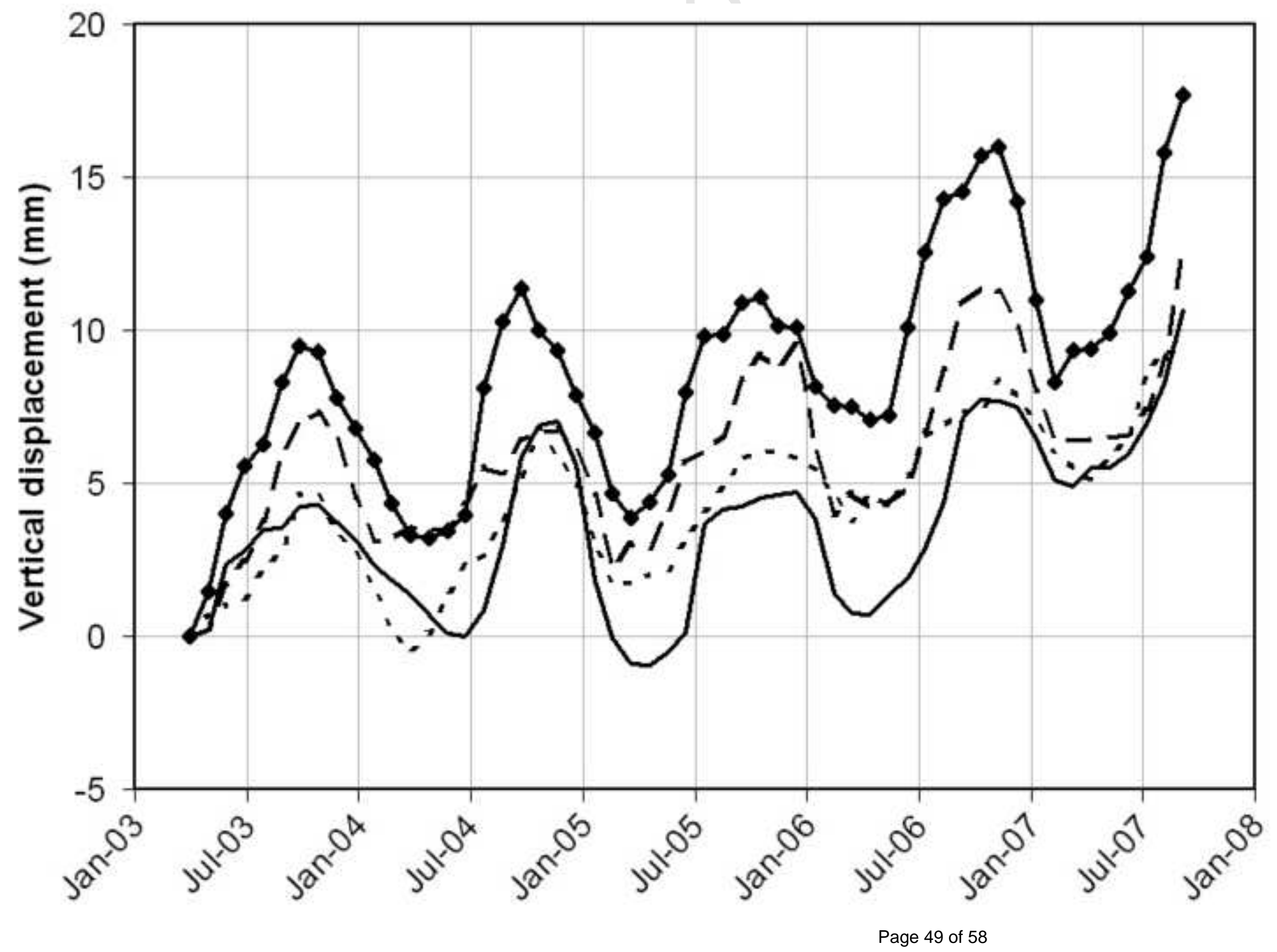




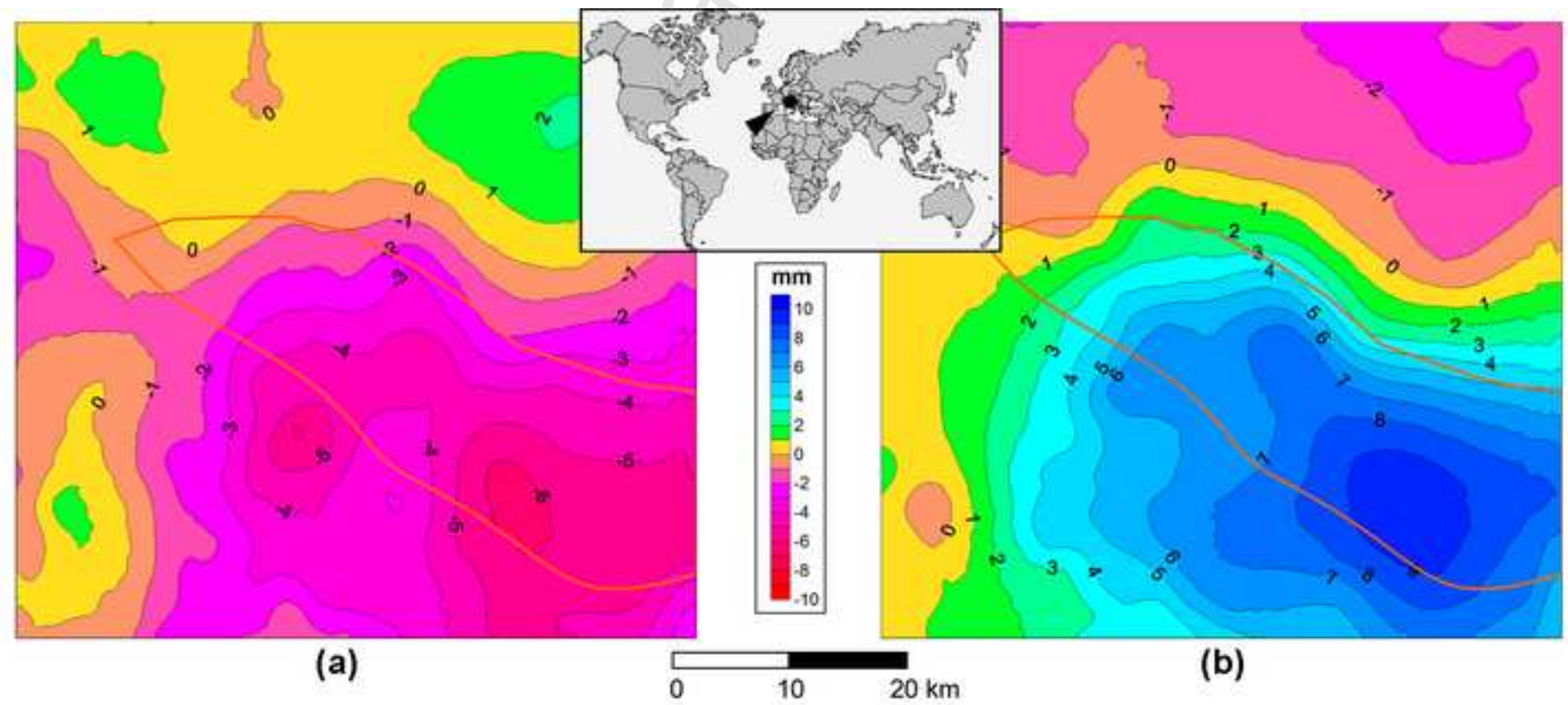



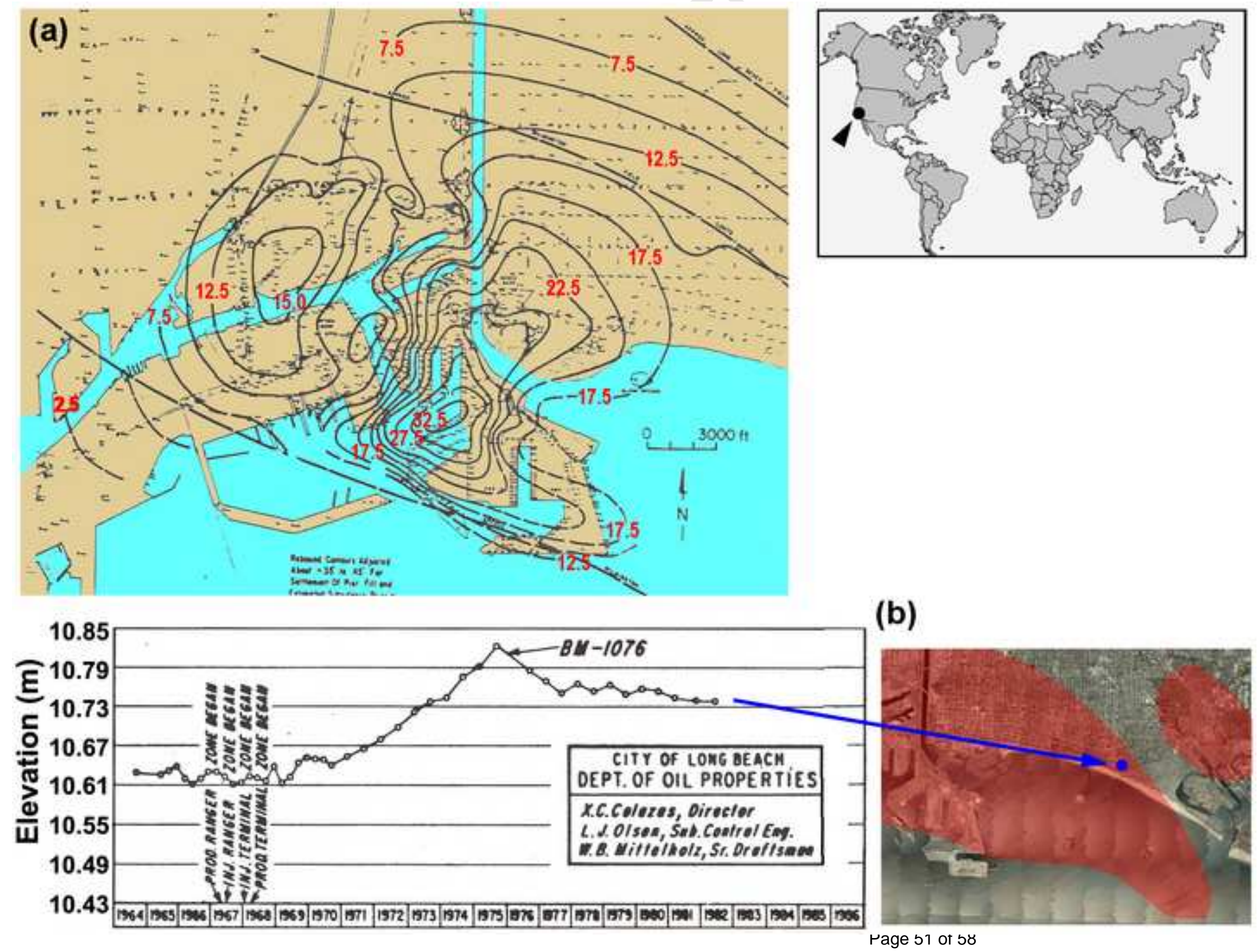

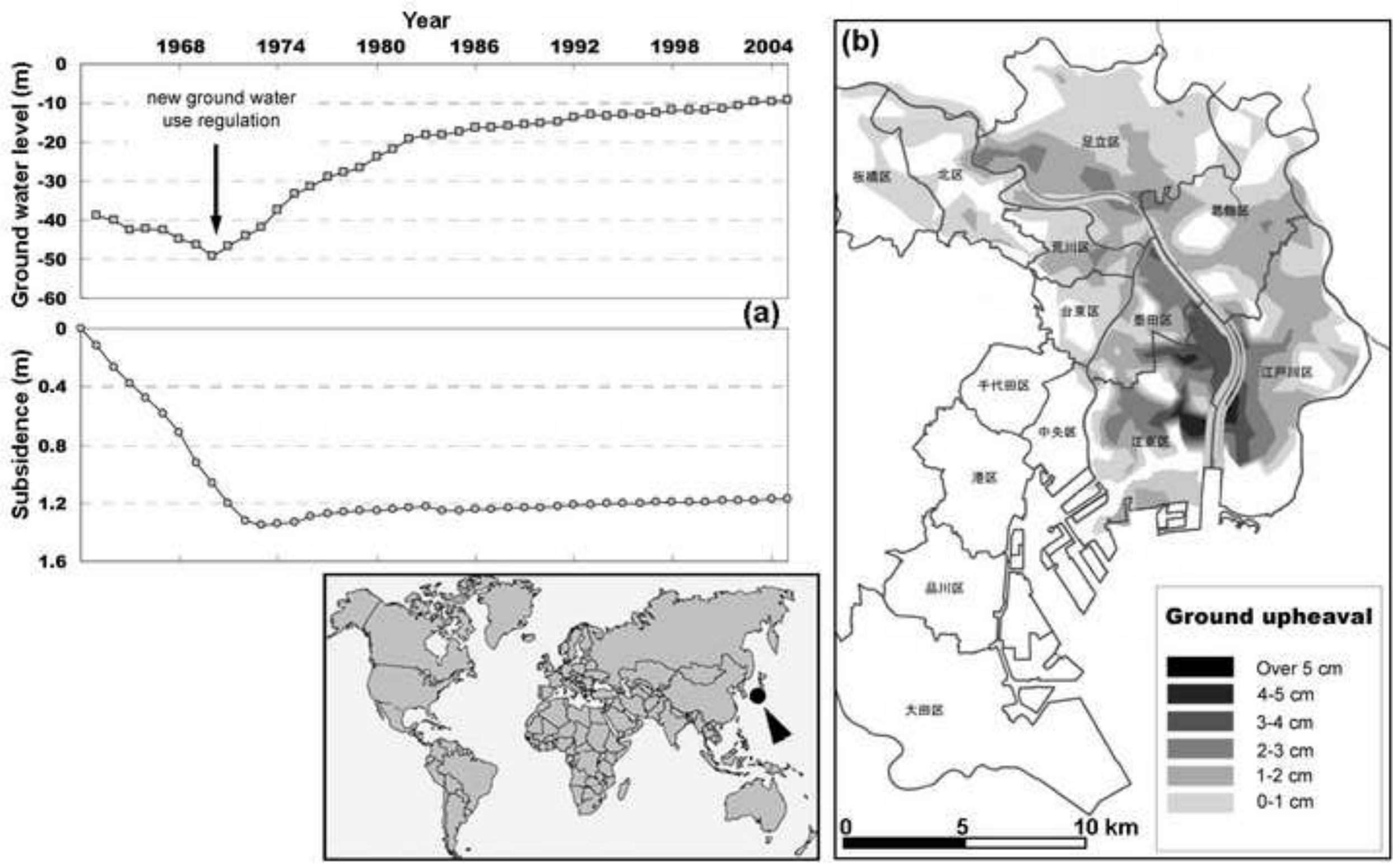

Page 52 of 58 


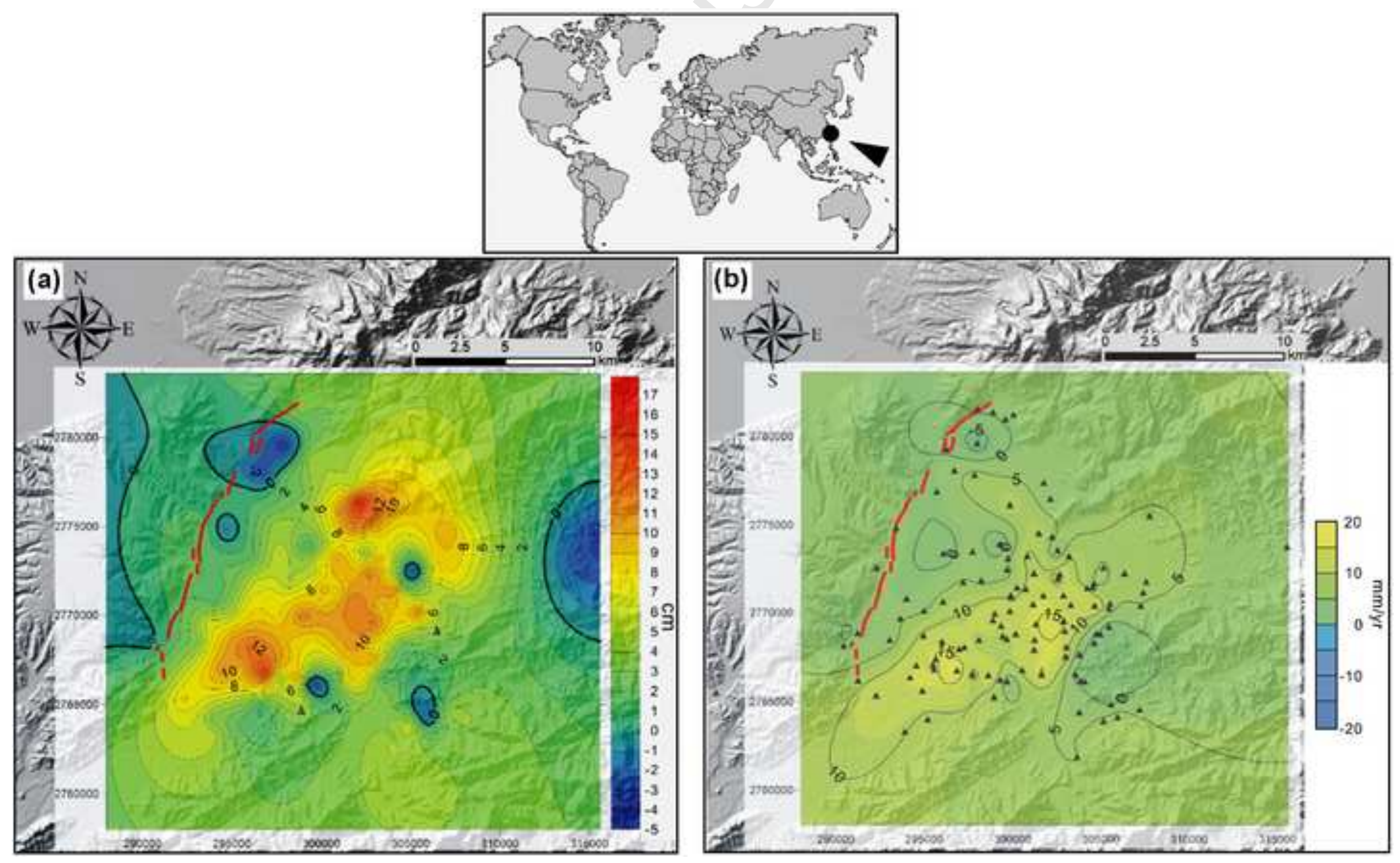




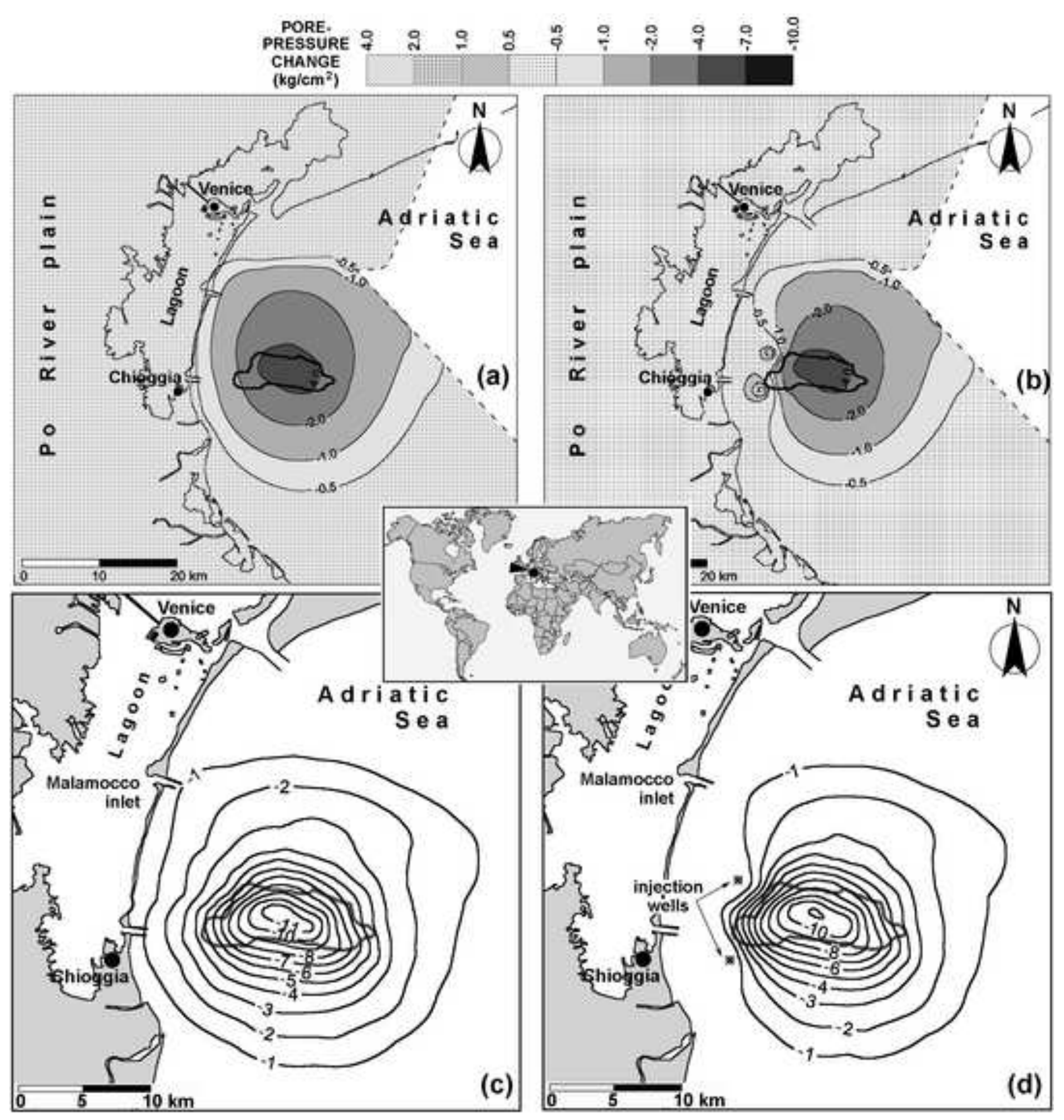




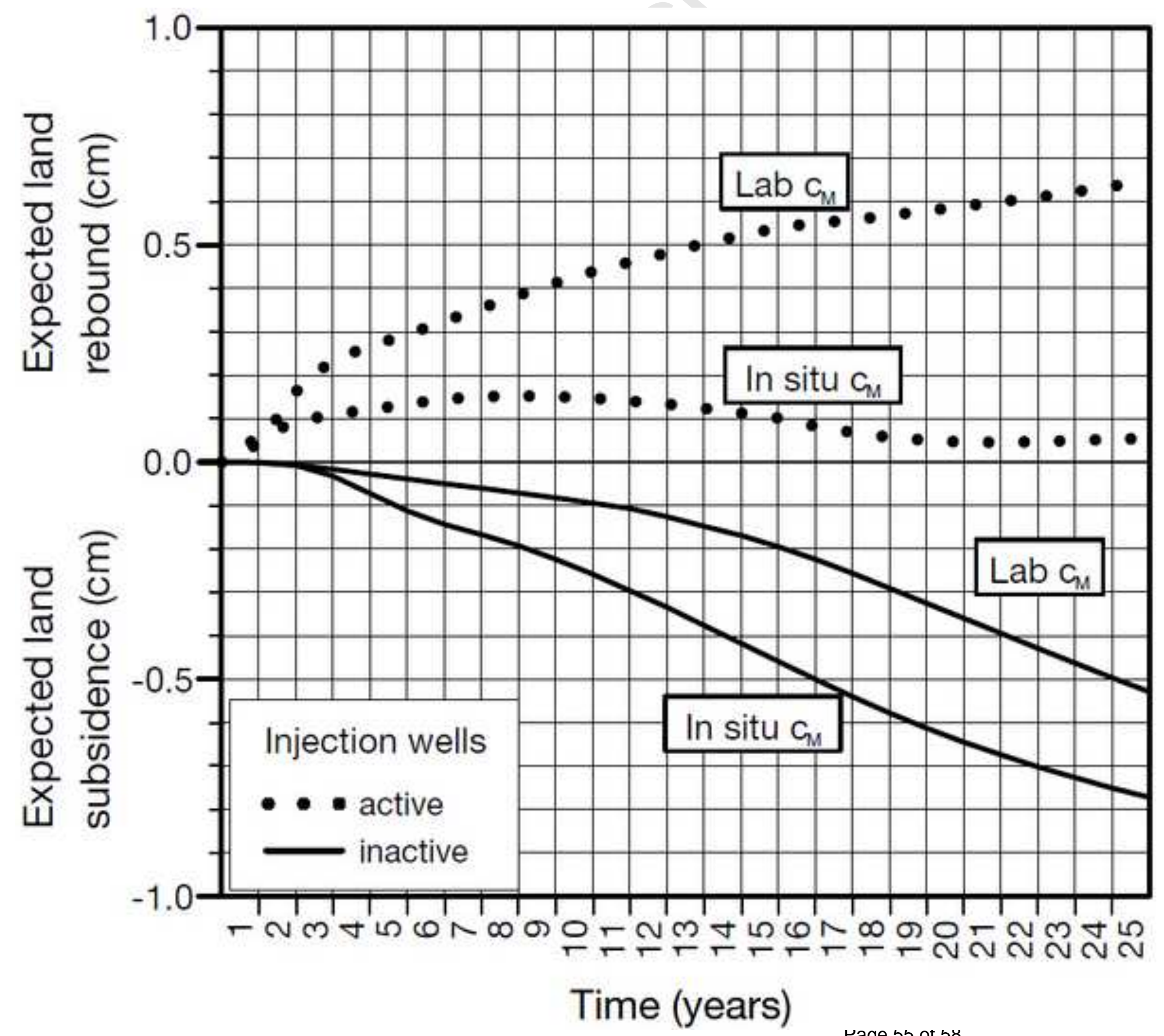

rage ๖ 


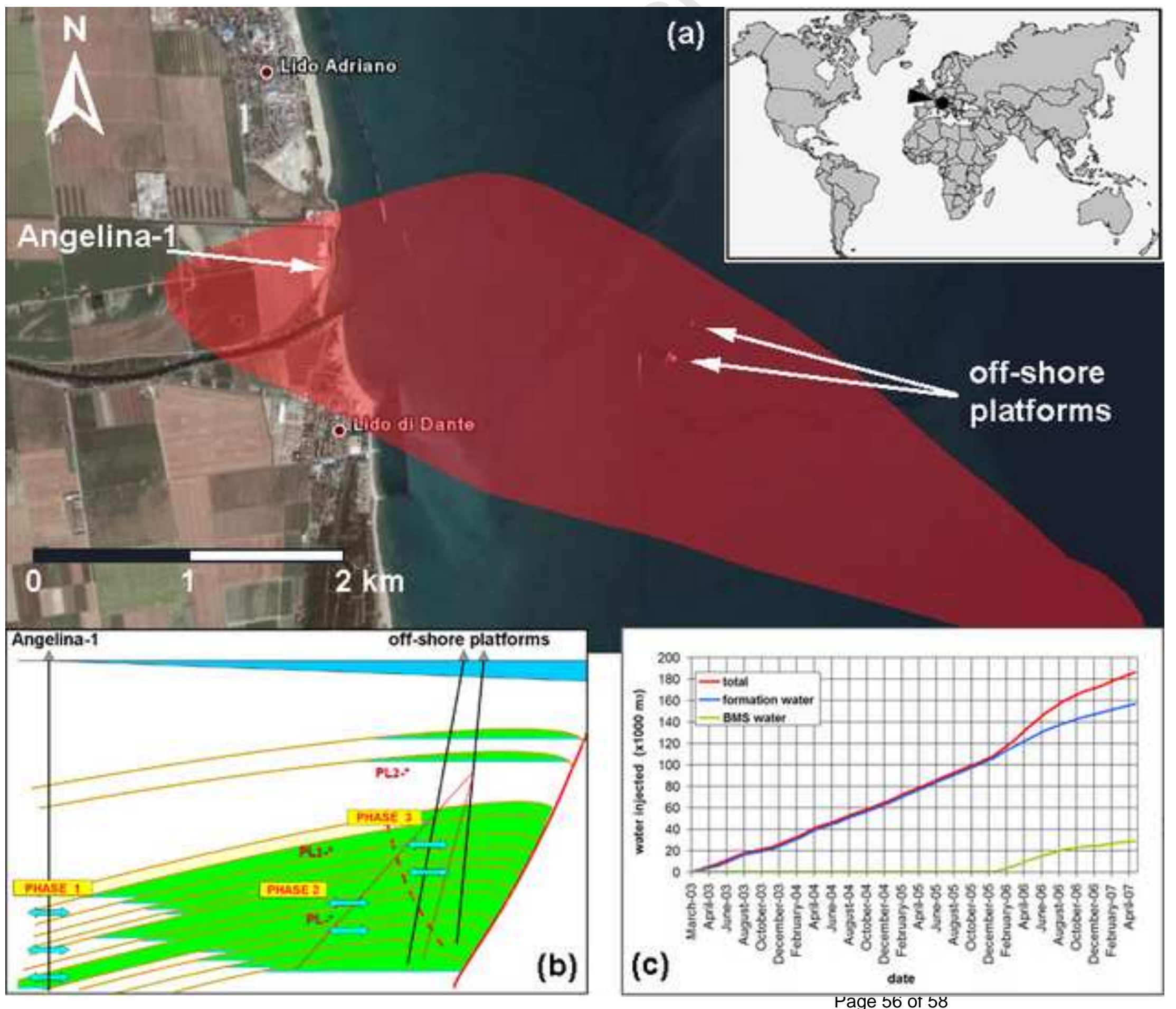

rage 56 oा 58 


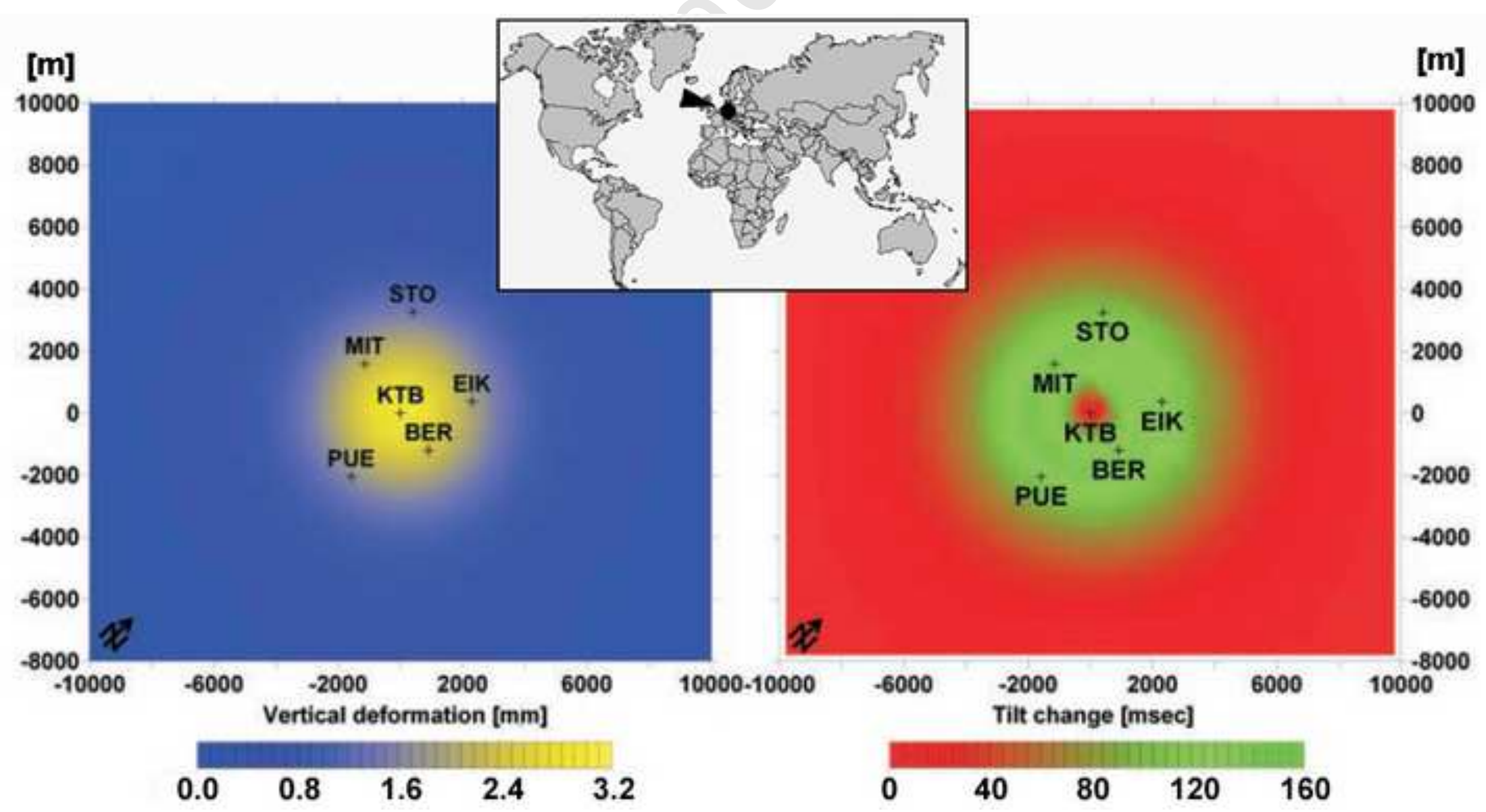




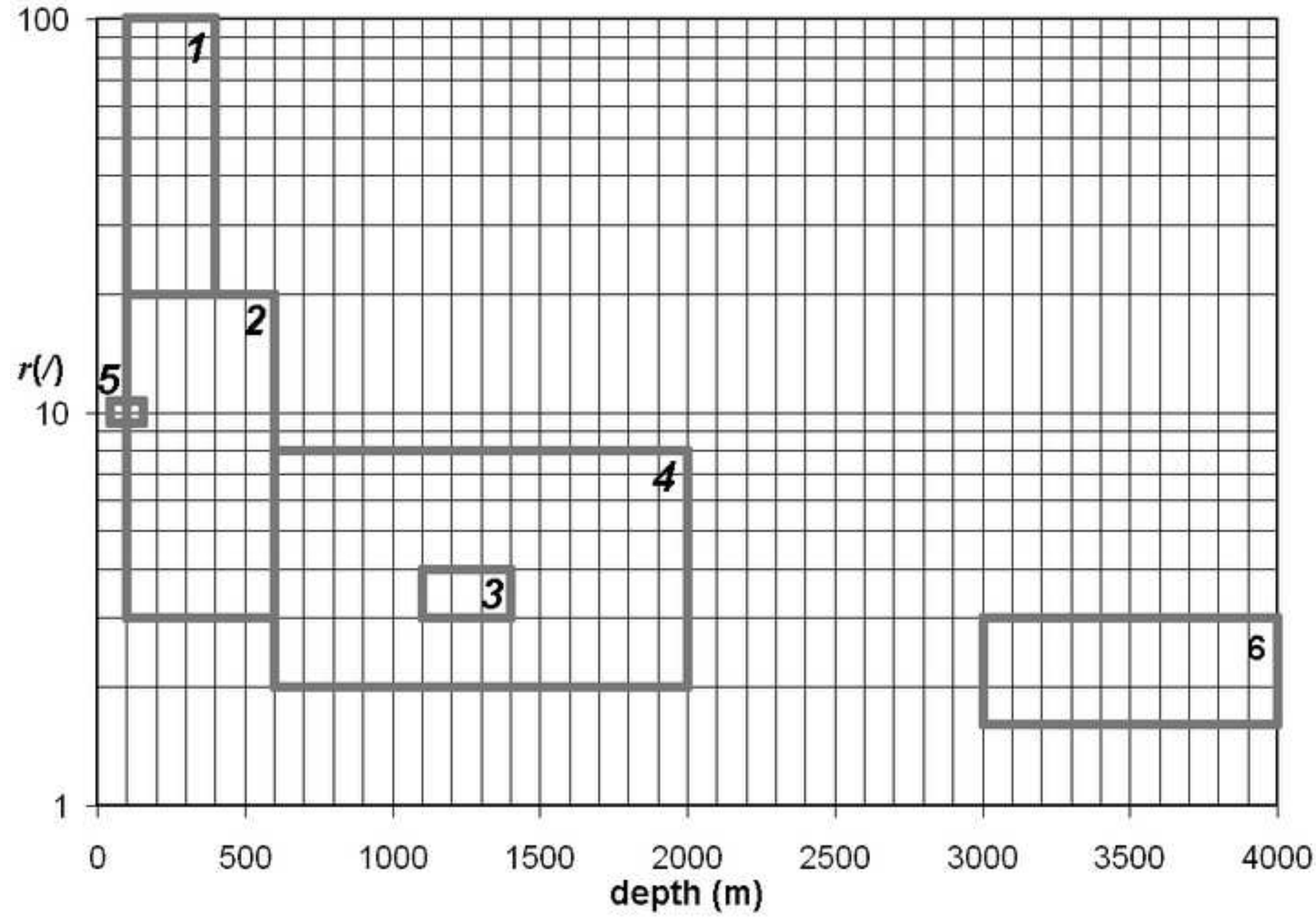

Page 58 of 58 